\title{
ACTING IN THE NAME OF CULTURE? THE PARTICIPATION OF ORGANIZED LABOUR IN THE CANADIAN BROADCASTING POLICY PROCESS
}

\author{
by \\ Amanda Coles \\ Bachelor of Arts, York University, 1996
}

\begin{abstract}
A thesis
presented to Ryerson University and York University

in partial fulfillment of the

requirements for the degree of

Master of Arts

in the Program of

Communication and Culture
\end{abstract}

Toronto, Ontario, Canada, 2005

(c) Amanda Coles 2005 


\section{UMI Number: EC53012}

\section{All rights reserved \\ INFORMATION TO USERS}

The quality of this reproduction is dependent upon the quality of the copy submitted. Broken or indistinct print, colored or poor quality illustrations and photographs, print bleed-through, substandard margins, and improper alignment can adversely affect reproduction.

In the unlikely event that the author did not send a complete manuscript and there are missing pages, these will be noted. Also, if unauthorized copyright material had to be removed, a note will indicate the deletion.

\section{$\mathrm{UMI}^{\circ}$}

UMI Microform EC53012

Copyright 2008 by ProQuest LLC

All rights reserved. This microform edition is protected against unauthorized copying under Title 17, United States Code.

ProQuest LLC

789 East Eisenhower Parkway

P.O. Box 1346

Ann Arbor, Ml 48106-1346 
Author's declaration

I hereby declare that I am the sole author of this thesis.

I authorize Ryerson University to lend this thesis to other institutions or individuals for the purpose of scholarly research.

Amanda Coles

I further authorize Ryerson University to reproduce this thesis by photocopying or by other means, in total or in part, at the request of other institutions or individuals for the purpose of scholarly research.

Amanda Coles 
Ryerson University requires the signatures of all persons using or photocopying this thesis. Please sign below, and give address and date. 


\section{ACTING IN THE NAME OF CULTURE? THE PARTICIPATION OF ORGANIZED LABOUR IN THE CANADIAN BROADCASTING POLICY PROCESS}

Amanda Coles

Master of Arts, 2005

Joint Graduate Programme in Communication and Culture

Ryerson University and York University

\section{ABSTRACT}

The thesis examines the role, efficacy and influence of the five national English-language independent film and television production sector unions in the Canadian broadcasting policy network. While labour is typically classified as a civil society organization within policy network studies, this thesis will examine the blanket applicability of this typology in analyzing labour's engagement with issues that involve both their vested economic/industrial interests as well as broader social/cultural goals, using the unions' engagement with the issue of Canadian dramatic programming from 1998 to present as a case study. 


\section{TABLE OF CONTENTS}

INTRODUCTION ................................................................. 1

CHAPTER ONE - Toward a Specificity of Language Through Evaluation................9

CHAPTER TWO - A Regulatory Framework for Canadian Television ................ 22

CHAPTER THREE - The History and Structure of Organized Labour in the Canadian

English Independent Film and Television Production Sector ........................ 32

CHAPTER FOUR - The Unions' Engagement with the CRTC over the 1999 Television

Policy and the Issue of Canadian Dramatic Programming .......................... 62

CHAPTER FIVE - Labour and the Representation of Interests in Policy Advocacy.... 84

SOURCES CONSULTED ........................................................ 100 


\section{INTRODUCTION}

The Canadian television broadcasting policy process functions on a public service model, balancing both cultural and industrial objectives in a single system with the notion of the public interest at the centre of its operations. In achieving this balance, the Canadian broadcasting policy process relies on both private and public interests to participate in the development and evaluation of policy and regulation related to Canada's public airwaves.

Central to the notion of the public interest in broadcasting is Canadian dramatic programming, a genre that does not necessarily work within the market rationale of the broadcasters but is seen by policy makers to contribute social and cultural benefits to the broadcasting system. I will use the CRTC's 1999 Television Policy as a point of entry to examine how the five national English-language film and television unions ${ }^{1}$ attempt to influence policy affecting Canadian dramatic programming. The 1999 Television Policy introduced significant changes to the regulations that affect the amount and type of Canadian content conventional broadcasters are required to schedule, the implementation of which, the unions argue, has been the direct cause of the decline in original Canadian dramatic programming.

I undertook the research with the following series of questions: How do film and television unions behave in the broadcasting policy arena? How do the mandates and structures of the unions as labour organizations affect their policy activities? How do the unions address policy issues that extend beyond the direct interests of their members to include broader social objectives? What strategies do the unions 
use to advocate their policies, and how effective are they in having their agendas addressed at the policy level? Does their policy framework reflect a genuine engagement with broader social issues? Can labour be discussed as a typology in and of itself, or are the labour groups involved in policy interventions disparate enough in their structure and activity to require specificity in accurately analyzing their roles in the policy network? In seeking to develop meaningful analysis of group activity and efficacy in the policy arena, how useful are the terms civil society organization, pressure group, advocacy group and interest group as used by scholars in analyzing group participation in the policy arena?

The unions intervene in a variety of cultural policy issues, from intellectual property rights to trade liberalization, tax reform, status of the artist and funding of film and television production. Through the lens of policy network analysis, my thesis will evaluate how the unions have revised their policy approaches specific to dramatic programming, improving their power and influence within the broadcasting policy network.

All the unions studied here participate in the production of both feature film and television formats. My thesis is only concerned with the unions' interventions around Canadian dramatic television programming in analyzing their power and efficacy as policy actors in the broadcasting policy network. Broadcasting is a highly regulated industry in Canada, utilizing a number of public processes in policy development and implementation. The transparent and accessible nature of the Canadian broadcasting policy process makes it a convenient site for policy network analysis. While television broadcasts represent an important window for the 
exhibition of Canadian feature films, the English language Canadian film industry is quite distinct from the English language Canadian television industry. Although state support exists for feature film production in terms of tax credits and funding agencies such as Telefilm Canada, Canadian film production and exhibition remains unregulated in Canada.

The Alliance of Canadian Cinema, Television and Radio Artists (ACTRA), the Director's Guild of Canada (DGC), the Writer's Guild of Canada (WGC), the Communication, Energy and Paperworkers Union (CEP) and the International Alliance of Theatrical and Stage Employees (IATSE) each have their own relationship to the Canadian film and television industry and cultural policy interventions. The unions' independent interventions at the public consultation process leading up to the 1999 Television Policy focused almost exclusively on their members' interests. I will argue that the release of 1999 Television Policy lead to the adoption of a coalition strategy, with the formation of the Coalition of Canadian Audio-visual Unions. This marks both a shift in policy strategy and in discourse.

\section{Methodology}

A thorough literature search revealed that the specific relationship of film and television unions to film and television policy in Canada has not been addressed. I found analyses of the role of the state in the development of Canadian broadcasting policy and regulation; policy community and network theory specific to the Canadian context; and examinations of the role of civil society organizations and 
other non-state actors to the shifting policy environment. This informs the backbone of my theoretical framework.

A search of primary documents revealed the important role the unions play in public processes. They present at Canadian Radio-television and Telecommunications Commission (CRTC) and Standing Committee on Canadian Heritage hearings and consultations, attend industry roundtable discussions, Finance Committee and Industry Canada meetings, and stage political rallies and protests.

I completed my research through interviewing key organizational representatives. In order to really understand how the unions work and how approaches to policy are developed and executed, it was crucial to interview those directly involved (or most likely to be involved in future) with policy activities ${ }^{2}$.

1 frame my discussion within policy network analysis. The term policy network describes the relationships amongst a set of actors within a policy community. The role of policy networks is to "formulate, implement and evaluate the effectiveness of policy" (Murray 2002: 335). Policy network analysis places policy subsystems, such as Canadian broadcasting policy and regulation, within the socioeconomic and political framework in which they operate. Policy network analysis is useful for two key reasons in exploring the relationships between policy actors. First, it reinserts into the literature an understanding of the role that politics play in shaping policy, moving the process toward a complex set of power relations and competing interests (Pal 2001). Second, policy network analysis examines shifts in governance that have significant implications for the democratic administration of public services such as the Canadian broadcasting system. 
The term policy community refers to the sets of actors either engaged directly with or observant to a specific policy arena. Members of the Canadian broadcasting policy community include industry representatives such as broadcasters, producers and unions, concerned public groups such as Friends of Canadian Broadcasting and members of the public at large who engage with the CRTC's public consultation processes, including community and educational groups and at times, individual citizens. Both Pross (1992) and Atkinson and Skogstad (1996) divide levels of policy communities into two main categories: the subgovernment, comprising those who wield significant influence in policy formation and decision making processes, and the attentive public, comprising those actors who follow and attempt to influence policy, but do not directly participate in the decision making process. Policy network analysis is key in determining whether a group is situated within the community as a member of the attentive public or the subgovernment, and will be used here to determine the status of the five unions as either members of the attentive public or subgovernment within the Canadian broadcasting policy network.

The thesis opens with an analysis of the shifting policy environment that has lead to an expansion of policy actors participating in policy consultation and decision making processes. I examine the language used in describing group activity in policy network theory, arguing that the various terminologies used in scholarship are more accurately used for specific case study analyses than as general typologies, as the nature of a group's activity is fluid rather fixed due to the shifting nature of groups themselves. This is exemplified by the evolution of labour's status and mandate 
within the policy network. I assess Pross' (1992) model of characteristics and functions of pressure groups as a tool for analyzing the ways in which groups behave and are positioned in the policy sphere. Application of Pross' model throughout the thesis provides the framework required to select accurate terminology which best characterizes these unions within the Canadian broadcasting policy network.

Chapter two examines the venues in which Canadian broadcasting policy happens, with particular emphasis on the CRTC - the central agency responsible for. the development of policy and regulation of Canadian broadcasting in accordance with the Broadcasting Act. The CRTC's regulatory history with Canadian drama, with a particular focus on the 1999 Television Policy, is analyzed in relationship to the agency's mandate to balance cultural and industrial interests within the public service model of Canadian broadcasting.

Chapter three situates the Canadian film and television industry and its workers in the globalized economy, providing an historical and organizational profile for each of the unions in order to analyze how their internal structure and philosophy affects their engagement with public policy in general and Canadian dramatic programming in particular. I draw heavily from scholarship related to the role of groups in policy networks, including Atkinson \& Coleman (1996), Murray (2002), Pal (2001) and Pross (1992). Research methodology in compiling the profiles examined size, location of national and regional offices, age and historical beginnings, jurisdictions, organizational structure and governance, examination of their mission statement and constitution where possible, requirements and benefits of membership, general organizational activities, budget and policy resources, 
affiliates and partnerships, main issues in policy intervention and a review of all key policy documents related to dramatic programming from 1998 to present. The unions' organizational policy capacity, ability to formulate policy positions and desire to influence rather than be the government are analyzed through the application of the first three questions in Pross' model in determining whether a group can be considered a pressure group within a policy network.

Chapter four examines in detail the unions' policy activity with respect to the introduction of 1999 Television Policy and the decline in Canadian programming that followed. It analyses their policy strategies and evolution of discourses in developing a balance of between industrial and cultural policy rationales, examining the adoption a coalition based strategy through the formation of the Coalition of Canadian Audio-visual Unions (CCAU). Using Pross' identification of group functions as a tool to evaluate the role of the unions in the policy network, the chapter shows how the recent coalition strategy employed by the unions, in finding strategic partnerships where interests coincide, has worked to promote the position and influence of the unions, increasing their power and efficacy in having their objectives achieved.

Chapter five analyses whether the unions are most appropriately located as members of the attentive public or the subgovernment in the policy community. 1 then evaluate the degree to which the policy strategies and discourses of the unions reflect engagement in the policy network as members of civil society working in the public interest. I conclude with a set of strategic recommendations that I believe will improve the unions' power and influence within the Canadian broadcasting 
policy network through expanding their constituent interests beyond those vested in industrial concerns toward the development of broader social and cultural policy networks. 


\section{CHAPTER ONE - Toward a Specificity of Language Through Evaluation}

The policy environment is shifting as a result of political, technical and socioeconomic developments, bringing changes that result in an increase of non-state actors involved in public policy development and implementation. I will analyze the shifting policy environment in order to establish the broader political-economic conditions in which Canadian broadcasting policy occurs, with a particular focus on the role of civil society actors in the policy process. Scholars have adopted and adapted a variety of terms, such as pressure group, interest group, civil society organization, and advocacy group, to describe the activity and role of non-state actors within the policy sphere. I will examine various rationales for each term and whether the terms describe actual differences in group constitution and behaviour or whether they are rather a reflection of a particular author's attempt to categorize certain non-state actors using the convenience of a single term. I will also analyze the terms' applicability in accurately describing the role of film and television unions in the Canadian broadcasting policy arena.

It quickly becomes clear that labels are best applied in reference to specific group activities around a particular issue or within a given timeframe. I will examine Pross' model for discerning the status and function of groups in the policy arena as a tool for evaluating the efficacy of the unions in the broadcasting policy sphere, in determining which terminology best represents these unions' policy actions around the issue of Canadian dramatic programming. 


\section{The policy environment}

Under the social and economic processes of globalization, the policy process is becoming increasingly complex. The proliferation of technological innovation and expanded integration of policy jurisdictions requires advanced knowledge and expertise for policy formulation and implementation.

Globalization as a social phenomenon, characterized by emi-/immigration and the explosion of global communication technologies, has enhanced access to information, leading to increased demands for transparency and accountability in state activities, as well as an increase in public expectations for involvement in government processes and decisions (Gattinger 2003, McDonald 2002). Globalization as an economic process compromises the sovereignty of the federal level of the state to act unilaterally in its policy decisions. Economic integration and rapid trade liberalization result in an increasingly complex relationship between the multiple jurisdictions in which policy is developed and implemented, linking international, continental, federal, provincial and municipal layers of the state in an intricate policy network where the policy activities at one layer affect those at the others (Clarkson 2001). The focus on economic integration and trade liberalization also privileges a market rationale in government activity, characterized in part by the New Public Management model within Canadian public administration.

The New Public Management model applies a business approach to the provision of public services. In the Canadian public administrative system, application of the model is marked by the need for budget restraint, reducing bureaucracy, developing a 'client' relationship with the public and enhancing 
public/private partnerships in the provision of public services (Dwivedi \& Gow 1999). The marketization of the state has impacted the policy arena and is reflected in policy language such as competition, efficiency, productivity, service, choice and flexibility (ibid) ${ }^{3}$. Concurrently, changing models of governance view public institutions as an expression of the public interest in policy and encourage the utilization of public-private partnerships as an alternate means of making and implementing policy (Peters 1998). Under both frameworks, the state is required to seek out new relationships with both civil society and the private sector under an increased pressure to deepen partnerships with stakeholders in the development and delivery of public policy.

These conditions have lead to a substantial expansion of actors participating in complex policy networks. Yet as Clarkson (2001) and Pross (1992) argue, the state remains the central organizing body in the policy process, responsible for the formulation and legitimation of policy directives despite the growing roles of the other policy actors. Atkinson and Coleman (1996) note that it is still the state in all its interconnected and multiple layers that shapes the policy environment, determining who is part of the policy process and conversely, who is not. Negotiating competing economic, social, political and cultural interests, the state relies heavily on civil society organizations to mitigate the power of private interests, providing greater balance to the perspectives of benefit (Murray 2002). Benefits to the state from increased consultation with civil society organizations include greater support for policy due to broader involvement of concerned and affected parties, increased transparency in government, a more active citizenry and 
improved relations (or public relations) between government and the public it represents (Gattinger 2003, Richardson 2000). Certainly, in meeting demand for increased public participation and requiring additional sources of information and expertise, particularly in broadcasting policy where technological innovation is so rapid, civil society assists the needs of the state in the public policy process.

The language on group behaviour in policy

The role of civil society in the development of public policy has generated much literature. Civil society is a concept with multiple meanings and connotations. Common amongst them is the notion of the public interest at the core of its use. As Murray (2002) notes,

Civil society can range from connoting a framework for values and norms (espousing social ideals of cultural tolerance, civil virtue, respect for human dignity, and so on) to denoting a collective noun. It can also designate a space for action separate from that of state and market; an historical movement...a social movement, critical of the cultural atomization of modern liberalism; or an antidote to (or surrogate for) the state (332).

Uphoff and Krishna (2004) observe that civil society has become a code word justifying engagement with non-economic concerns, and use it to refer to, "a set of institutions and relationships that affect the balance of power between the state and citizens in favour of the latter" (358).

However, Salter (2004) notes there is a disturbing trend in scholarship on the role of civil society organizations in public policy to argue that civil society actors necessarily work in protecting or promoting the public interest. I contend that the unquestioning conflation of civil society organizations' policy interventions with the 
public interest is as theoretically dangerous as conflating public and private interests in policy design and implementation. Simply assuming that civil society organizations work in the public interest does not take into account civil society organizations such as white supremacy associations or even professional associations (such as unions) whose purpose may be to advocate for expressly private concerns as members of the public (Salter 2004). Another troubled aspect of scholarship on the role of civil society in public policy is that it does not often take into account the power relations between civil society organizations in the policy process. A trade union will likely (albeit not necessarily) have more resources and expertise at its disposal for policy intervention and influence than a concerned citizen's group or block association. While labour organizations are widely considered to fall under the vast umbrella of civil society organizations, to discuss them in this framework erases the characteristics specific to the role of labour in the policy processes (Murray 2002, Pal 2001, Uphoff and Krishna 2004). Labour has an important role to play, but it is as a labour organization, not to be confused or conflated with other civil society representatives who, depending on the wide variety of definitions available, can range from the broadcasters to the Girl Guides.

The unions of this study enter the broadcasting policy network primarily as representatives of the interests of their specific publics - the workers in the Canadian film and television industry. In this sense, they, as all groups participating in the broadcasting policy network, are interest groups. In denoting the vested industrial interest the unions have not as members of civil society generally, but as politically motivated labour representatives, I will apply the term, 'constituent' to 
'interest group' in describing these unions' policy interventions with respect to dramatic programming. The term constituent interest group also functions to distinguish them from a public interest group that, "purports to represent very broad, diffuse, non-commercial interests" (Schuck in Pal: 239).

Pross (1992) notes that 'interest group' and 'pressure group' are often used interchangeably in policy community and network theory. Pross prefers the term 'pressure group', arguing that 'interest group' is vague, conveying a sense of general, non-political group activity. For Pross, the term 'pressure group' denotes the political nature of the actions taken toward achieving a policy direction, arguing that an inherent quality of a pressure group is their ability to threaten sanctions in applying pressure in lobbying activities (ibid).

My analysis leads me to conclude that this ability to threaten sanctions is not within the scope of the unions of this study - they simply do not have that much power within the broadcasting policy network. While the unions do have the ability to go on strike, such actions are not undertaken in the context of their policy activities, but rather in the nature of their more general activities as organized labour representatives, and thus cannot reasonably be applied in this context. Similarly, Everitt and Young's (2004) use of 'advocacy group' is equally unsuitable for this analysis. The definition of advocacy groups as those that act in the best interests of their members as well as in the promotion of opinions in which they do not have a direct interest does not accurately reflect the perspective of the unions in the broadcasting policy community. While the unions draw heavily on notions of the public interest inherent in broadcasting policy discourse and documents in 
shaping their policy rationales, and some of the unions have organizational philosophies that would indicate a commitment to working toward cultural policies that operate first and foremost in the broader public interest (as defined by them), within broadcasting policy they focus mainly on promoting policies that benefit their members.

\section{Which public, whose interests?}

The notion of the public interest draws heavily in theoretical literature from a Habermasian notion of the public sphere as a space where individuals can come and go at leisure as equals in discussing, debating and determining guiding principles, or, in political arenas, policies that work to the benefit of society as a whole (Fraser 1993). As the notion of the public interest is at the core of broadcasting policy in Canada, I will examine the implications for the widespread and uncritical use of the term within the context of its use in broadcasting policy. I argue that use of the term 'public interest' as a singular concept does not effectively recognize the power relations within Canadian society or multiple interests that should be reflected in the Canadian broadcasting system.

Fraser (1993) problematizes the notion of the public sphere as inclusive, arguing that Habermas' model does not effectively account for social, political, economic and cultural power relations. These power relations, in practice, work to exclude certain groups, or publics, from the public sphere. Concepts such as democracy, equality, and freedom are often used to support rather than dismantle the power relations that (re)produce dominant groups (ibid). Privileging the concept 
of a single public sphere necessarily produces a dominant group and other competing publics are, "less able than otherwise to expose modes of deliberation that mask domination by absorbing the less powerful into a false 'we' that reflects the more powerful" (ibid: 14). Fraser reconceptualizes the notion of the public sphere to one of multiple public spheres. This works within a diasporic model of citizenship to provide for subjective readings, multiple identifications and critical reflections on personal, community and broader social concerns. As Jacobs (2000) notes, subaltern counter-publics need not necessarily be theorized as a site to replace participation in the dominant public sphere. Rather, subaltern counter-publics can operate as a space to, "contemplate and discuss ideas in the dominant, to argue and formulate positions, engage in discussion and matters and to correct the prejudices and misrepresentations which resulted from engagement in those other public spheres" (Jacobs 2000: 29).

The fundamentals and objectives of the 1991 Broadcasting Act both define, and state that the Canadian broadcasting system should operate in the public interest ${ }^{4}$, and much of the unions' interventions are discursively constructed within this context. Yet, issues around broadcasting are not necessarily the same for aboriginal populations as they are for deaf Canadians, for remote communities as they are for urban neighbourhoods, for Anglophone and Francophone audiences, or white audiences as they are for viewers who identify as visible minorities. Applying the notion of multiple publics, in the interests of re-inserting power relations into the ways in which broadcasting policy and regulation is discussed, moves the concept of the public interest toward a fluid and dialectic concept subject to 
influence from a wide range of factors. When examined in this framework, the notion of 'the' public interest becomes necessarily complicated. The term, 'public interest' will be used throughout this paper to refer to the objectives laid out in the Broadcasting Act and as taken up by the unions. However, in the interests of furthering a meaningful conversation on this concept within broadcasting policy discourse, I propose a more useful term would be, 'publics interests,' indicating the heterogeneous and diverse range of concerns and voices the Canadian broadcasting system is mandated to address and represent in both its structure and content.

\section{What groups do and they do and how they do it - an evaluative model}

The language used within the literature to describe both the groups and the interests they represent is often imprecise. Use of the terminology often shifts in focus from what groups do to a reification of what they say they are, raising problems similar to those explored within identity politics. The terminologies all describe some aspect of a group's behaviour, but do not necessarily accurately describe the nature of the group itself. All groups, including the unions studied here have interests in policy interventions. The unions interests can be seen to be constituent, as members of the policy community with a clear and material stake in an issue, or as a civil society organization advocating broader social and cultural goals based on their discursive construction of the issue. Thus the need is to examine less what the unions are in terms of a fixed typology, but where, when and how theses unions employ various strategies in attempting to have their agenda recognized and realized within the policy environment. A shift away from embroiled 
battles of language toward an analysis of specific case studies such as the one contained herein provides a useful framework for establishing the status and evaluating the efficacy of a policy community group within a policy network. Two key elements of Pross' (1992) work will be used within the context of this analysis. First is Pross' framework for determining whether groups even qualify as what he terms 'pressure groups', and what will be referred to herein as 'constituent interest groups', within a policy community. Pross identifies four key characteristics of pressure groups within a policy network. Whether the unions exhibit these characteristics will be analyzed through posing the following questions:

1. Are the unions organized in a formal capacity?

2. How able are they to aggregate and articulate common interests?

3. Do they exhibit a desire to influence the government rather than be the government?

4. Do the labour organizations try to persuade the Canadian federal government to pursue the policies they advocate?

(Pross 1992: 3-4)

Scholars have emphasized that the relationship of non-state actors to the state in encouraging and fostering policy networks is reciprocal in nature. Both sets of actors stand to gain substantial benefits from broader engagement of a wider variety of actors in the policy process (Gattinger 2003, Newman and Tanguay 2002, Pross 1992, Uphoff and Krishna 2004). It is argued that the de facto power of the state under the current policy environment has not been irrevocably eroded, and that the distribution of power in the policy arena need not necessarily be framed in terms of a zero-sum equation. Pross (1992) identifies the four main functions of interest groups within policy networks as those of communication, legitimation, regulation and administration. This model renders explicit how networked 
relationships with the state can benefit not only the interest group working toward its own specific goals but the state and other networked actors as well. In evaluating the power and influence of the unions within the broadcasting policy network, I will apply this model, adding the unions' ability to challenge the state as a key fifth function.

A primary function of constituent interest groups is to facilitate communication: both the demands of the publics they represent to the government, and the views of the government to the concerned publics and, at times, to a broader social audience. Through an integrated approach to policy monitoring and intervention where they engage with multiple layers of the state, interest groups can also serve the function of communicating messages and information intragovernmentally, between agencies within a level of government as well as between levels of government, i.e. from provincial to federal. Interest groups also communicate information between groups in the policy community, a critical function when developing strategic coalitions. Pross further notes that it is not only the message that groups communicate that is important, but the means by which that message is delivered. In their method of communication, groups have agenda setting capacities, and can prove crucial in helping governments prioritize issues. Groups can assist with the daily regulation and administration of the policy sector. There is a noticeable trend under the New Public Management model toward self-regulation and voluntary best practices and codes of conduct. This style of selfmanagement and surveillance plays an important role in assisting the state with the daily operations of a particular policy sector. As the state accords responsibility for 
such functions to non-state members of the policy community, the state also inherently legitimates that group's role within the policy process, improving both status and power. (Pross notes that these two functions, regulation and administration, are less significant functions than the previous two, as these tend to have less of a direct impact on the political system per se).

Interest groups legitimate the state when they acknowledge or support an individual, department, policy or program. Enhanced public participation and citizen engagement is beneficial for state-society relations and democratic processes. Conversely, government recognition of an interest group legitimates that group's status as a policy actor, enhancing their power and profile within the policy network.

I will add one other crucial role to the model that characterizes the relationship of interest groups to the state, and while this may not serve in as reciprocal a fashion as the above noted functions, it has important implications for the democratic administration of public services and systems such as Canadian broadcasting. Interest groups often, albeit not necessarily, challenge state policies and practices, a function that is increasing as the range of actors involved in the policy community expands. For each set of interests that are met within a policy framework, others are excluded or overlooked. While many groups, in their work of interest promotion, seek to maintain the status quo or improve their privileged position in the policy community, others seek to address what they consider to be fundamental structural or ideological imbalances in the policy process that work to the detriment of their organization and its concerned publics. While those groups 
who seek to maintain the current environment may be doing so for the time being, a shift in power or political imagination from any of the multiple layers of the state involved in policy formation may critically affect their positionality within the policy community. Thus, for groups to remain effective both as active network members and as proponents of their members' interests, they must at least have the capability to effectively challenge the state. 


\section{CHAPTER TWO - A Regulatory Framework for Canadian Television}

The Broadcasting Act and the CRTC are the two key elements that govern the Canadian broadcasting system ${ }^{5}$. Both are centered around the delicate act of balancing economic, industrial, social and cultural objectives. This chapter will examine how this balancing act and notion of the public interest is positioned at the heart of both 1991 Broadcasting Act and CRTC as the agency that is mandated to ensure the goals contained within the legislation are being achieved. The chapter will introduce the CRTC's relationship with Canadian dramatic programming, an issue at the crux of the push-and-pull of competing industrial/economic and social/cultural goals. The chapter highlights how the prevailing political and economic climate has shifted the balance toward industrial over cultural objectives with an increase in regulatory flexibility, and establishes the grounds on which the unions make their case for Canadian dramatic programming.

The principles that inform the 1991 Broadcasting Act extend the function of broadcasting well beyond a technical infrastructure for an entertainment industry. The Act is explicit in outlining the industrial and social objectives of the broadcasting system.

The Canadian broadcasting system, operating primarily in the English and French languages and comprising public, private and community elements, makes use of radio frequencies that are public property and provides, through its programming, a public service essential to the maintenance and enhancement of national identity and cultural sovereignty (Canada 1991: Section 3b)

the Canadian broadcasting system should

serve to safeguard, enrich and strengthen the cultural, political, social and economic fabric of Canada (ibid: Section 3 (d)(i) 
encourage the development of Canadian expression by providing a wide range of programming that reflects Canadian attitudes, opinions, ideas, values and artistic creativity, by displaying Canadian talent in entertainment programming and by offering information and analysis concerning Canada and other countries from a Canadian point of view (ibid: Section 3(d)(ii))

through its programming and the employment opportunities arising out of its operations, serve the needs and interests, and reflect the circumstances and aspirations, of Canadian men, women and children, including equal rights, the linguistic duality and multicultural and multiracial nature of Canadian society and the special place of aboriginal peoples within that society (ibid: Section 3(d)(iii))

each broadcasting undertaking shall make maximum use, and in no case less than predominant use, of Canadian creative and other resources in the creation and presentation of programming...(ibid: Section $3(f)$ )

The Canadian state has historically viewed the broadcasting system not only as a means to facilitate communication amongst its citizens, but a means by which national culture and identity is formulated. The importance of television broadcasting as a tool of social cohesion and nation building dates back to the Massey Commission of 1951. At the time of publication, television was only an emerging technology. The Commission foresaw the threat of private stations becoming vehicles for American programming, compromising the ability of Canadians to use the system as a tool for communicating Canadian ideas and stories. Forecasting the pervasiveness and popularity of television as a vehicle for mass communication, the Commission was overt in its view that the principles that should govern Canadian television broadcasting should work primarily toward the needs and interests of the Canadian people - principles which continue to be reflected to present day in the Broadcasting Act. The Commission recommended that the CBC play the central role in television policy development and licencing in Canada to 
ensure these cultural objectives would not be subsumed by private interests (Royal Commission 1951: 300-305). In adopting an arms-length principle to broadcasting policy and regulation, responsibility for television broadcasting policy and regulation fell to an arms-length agency, the Board of Broadcast Governors, which from the outset wrestled with the balance of public and private interests in the single system (Dorland 1996). The BBG initiated policy discussions on Canadian content regulations in the late 1950s. The discussions brought to the fore of policy debates questions regarding the amount of Canadian content required to meet the objectives of the Broadcasting Act, and whether Canadian content should be defined through the citizenship of the cultural artists who create the product, or the content of the programming itself (ibid).

The BBG became the CRTC in 1968. The CRTC is Canada's regulatory body governing broadcasting and telecommunications systems, and primary venue for the development, implementation and negotiation of broadcasting policy. Established in 1968 as the Canadian Radio and Television Commission, its jurisdiction was expanded in 1976 to the Canadian Radio-television and Telecommunications Commission (CRTC 2005). The CRTC is constituted through the Canadian Radio-Television and Telecommunications Commission Act, and is governed by Canada's Broadcasting Act of 1991, the Telecommunications Act of 1993 as well as the Bell Canada Act (ibid). It is an independent, arms-length authority comprised of up to thirteen full time Commissioners and up to six part time Commissioners, all of whom are appointed by the Prime Minister for renewable terms of up to five years. There is one Chair, and two Vice Chairs, one each for Telecommunications and Broadcasting sectors. The 
CRTC reports to Parliament through the Minister of Heritage, and is subject to orders from Cabinet in its directions (ibid).

The mandate of the CRTC is, "to regulate and supervise all aspects of the Canadian broadcasting system as well as to regulate telecommunications common carriers and service providers that fall under federal jurisdiction," and their role as regulator of broadcasting is, "to maintain a delicate balance - in the public interest between the cultural, social and economic goals of the legislation" (ibid). In meeting their objectives, the CRTC seeks public and private sector input through a variety of undertakings, including public hearings, calls for submissions, applications and a complaints process. As gatekeeper for the broadcasting system, the CRTC must ensure the needs of both private interests, such as the broadcasters and the unions, and the public(s) are being addressed, using the Broadcasting Act as their legislative beacon. The political economy of the Canadian television industry makes this a uniquely challenging job.

Being geographically positioned next to the U.S, with the largest entertainment industry in the world, has posed specific challenges in developing and preserving the Canadian-ness in the Canadian broadcasting system. Since U.S. producers and distributors of television programming are able to not only recoup their costs but also often reap significant profits within their domestic market, they are able to sell broadcast licence agreements to foreign markets (such as Canada) at significantly reduced rates ${ }^{6}$. This is particularly significant when examining the production of dramatic programming, the most expensive type of programming to undertake. Canadian broadcasters are able to purchase extremely popular U.S. 
dramatic programming that will guarantee significant advertising revenues at a fraction of the costs of producing original Canadian dramatic programming. As an added disincentive for broadcasters, the size of the Canadian market is a fraction of that of the U.S., making it extremely difficult for producers and broadcasters to recoup their costs in the domestic market, regularly resulting in net losses for this type of programming.

To mitigate market deficiencies and ensure the broadcasting system operates in the public interest, the CRTC developed a variety of regulatory measures in the interests of providing access to a selection of various types of programming, and dramatic programming in particular, to Canadian audiences.

The CRTC's 1983 policy statement on Canadian dramatic programming documented the importance of original Canadian drama within broadcaster's schedules. At the time, drama represented $49 \%$ of viewing at the time on English language television, and $66 \%$ of viewing in prime time. However, only $5 \%$ of the scheduled dramatic programming was Canadian, and Canadian-produced dramatic programming only represented $2 \%$ of all viewing time (CRTC 1983). Canadians were watching drama; they just weren't watching Canadian drama. In its policy statement, the CRTC discussed the cultural implications of the economic and industrial barriers to the production and exhibition of Canadian dramatic programming.

...if Canadians do not use what is one of the world's most extensive and sophisticated communications system to speak to themselves - if it serves only for the importation of foreign programs - there is a real and legitimate concern that the country will ultimately lose the means of expressing its identity. Developing a strong Canadian program 
production capability is no longer a matter of desirability but of necessity. (ibid: 3 )

In promoting the reflection of Canadian points of view, Canadian content regulations dating back to 1970 outlined what qualified as "Canadian" programming, and dictated that at least $60 \%$ of broadcaster programming overall, and $50 \%$ in the evening periods, must qualify as Canadian content (CRTC 1983). To ensure a variety of programming, particularly drama, in 1983 the CRTC introduced "priority programming" requirements that set programming minimums for Canadian drama ${ }^{7}$, music and variety programming (ibid). Furthermore, in an attempt to ensure such programming was sufficiently financed, the CRTC also set priority programming expenditure requirements as conditions of licence for Canadian conventional broadcasters. Such regulatory initiatives were seen to work toward economic objectives in developing a domestic industry infrastructure as well as cultural concerns in telling Canadian stories from a Canadian perspective (CRTC 2003).

In 1999 the CRTC took a new direction in their policy rationale, one that much more closely reflected principles associated with a market approach to public policy. The 1999 Television Policy, which outlines the regulatory framework for private conventional television, evidenced this shift wherein three of the five stated principles of the policy clearly emphasize elements of New Public Management. In addition to striving to provide quality programming reflective of Canada's diverse population, the key elements of the framework are to ensure, "an economically successful broadcasting industry, require regulation only where the goals of the Act cannot be met by other means (and) ensure that regulations are clear, efficient and easy to administer" (CRTC 1999: 2). At the news conference announcing the new 
policy, Chair Francoise Bertrand stated the major private television networks were an "essential component of the Canadian broadcasting system," and the CRTC had, "determined that the best way to support them would be to focus on groups of television stations and to let them choose their own image branding and give them the necessary leeway to achieve this goal" (Bertrand 1999). Broadcasting is referred to in almost exclusively industrial and economic terms throughout the 1999 Television Policy, wherein the policy is designed to, "support an economically successful broadcasting industry," "contribute to making the economics work," ensure that, "conventional TV remain(s) profitable," recognize that, "ownership groups have grown in size, (and) become stronger competitors in both domestic and international markets," and applaud the, "business acumen of those individuals who built dynamic businesses" (CRTC 1999).

Two of the most contentious changes to the regulatory structure under this new policy framework were the expansion of priority programming categories and the removal of broadcaster expenditure requirements. The expansion of priority programming categories meant that broadcasters could now meet their minimum exhibition requirements for priority programming through such formats as long form documentaries and "reality" tv shows, genres that are significantly less expensive than drama to produce. In addressing the issue of drama and recognizing the economically prohibitive nature of dramatic programming, the CRTC implemented a credit initiative wherein dramatic programming of 30 minutes or more that qualified for a full 10 points under the CRTC Canadian content qualification would receive a $150 \%$ dramatic time credit applied against priority programming in peak periods. The 
Commission also introduced a $125 \%$ time credit for Canadian drama that did not qualify for the full 10 points but was still certified as Canadian by the CRTC (ibid). This effectively allows the broadcasters to schedule additional foreign programming during peak viewing times.

The removal of expenditure requirements meant that broadcasters were now free to spend as much or little as they saw fit on drama and other types of priority programming in meeting the regulatory requirements. Private broadcasters had long been lobbying for a framework that was driven more by an industrial economic rationale than cultural objectives. The policy also reflects a distinct shift toward viewer as consumer rather than viewer as citizen in its explanation for the removal of expenditure requirements.

The Commission believes that, in a competitive environment, licensees require high quality programming to win audience loyalty...The Commission is concerned that the existing expenditure requirements are complex and may not provide licensees with the flexibility they require to adapt their programming strategies to a highly competitive marketplace. (1999: 5).

Ironically, Harvey notes that this type of framework for broadcasting regulation may in fact lead to decreased choice for viewers in a scenario where broadcasters, "rush to the middle ground in the commissioning of programs, and where ratings anxiety and risk aversion become the sad progenitors of unadventurous programming" (2004: 199). Research indeed evidences a serious decline in the amount of Canadian drama broadcast in the years following the new policy's implementation. In 1999 the total number hours of Canadian drama broadcast was 753. By 2001, that number had fallen to 587 (CCAU 2003). 
Subsequent broadcaster licence renewals revealed little emphasis on the importance of original Canadian dramatic programming. The power to grant, renew and set the conditions for broadcasting licenses is one of the principal powers of the CRTC. Licence renewals are the most opportune moment for the agency to address issues with broadcaster procedures and practices, hold broadcasters accountable to the CRTC for their commitments made in previous years, and require them to demonstrate their obligation to operate in the public interest (Raboy and Taras, 2004). The CRTC has a variety of tools it can employ in enforcing broadcaster compliance, ranging from soft encouragement in outlined expectations to more concrete measures including conditions of licence, short-term renewals, mandatory orders and rarely, suspension, revocation or non-renewal of the licence.

Despite the documented decline in dramatic programming since the policy's implementation, the Commission did not address this issue at all in the major broadcaster's licence renewals. Rather, the Commission's 2001 decision to renew Global for the full seven year term reflects a commitment to the emphasis on regulatory flexibility; the Commission articulates the ongoing need for drama in setting Conditions of Licence that require Global to broadcast an average 3 hours per week of drama or long-form documentary for the first two years of the licence term and four hours thereafter within the expanded definition of prime time between 7:00 and 11:00pm, yet the language used in the decision with regard to the enforcement of this condition indicates a great deal of discretion will be left to the broadcaster (CRTC 2001). The Commission expects the distribution will be reasonably even throughout the week; they will expect most of the programming 
will not come from in-house resources but rather will be performed by independent production companies; expects them to engage with priority programming from all regions of Canada and will monitor audience levels for priority programming, "to ensure that the goals of the Television Policy are achieved" (ibid: 5). The CTV renewals issued at the same time are similar in substance. Despite the fact that CTV's schedule reflected a complete absence of Canadian priority programming on three nights of the week, and half of what was programmed was aired on Saturday night, the Commission's only regulatory directive was that it, "expects that each station's schedule will reflect a reasonable distribution of priority programming both throughout the week and the broadcast year" (CRTC 2001a: 7) Furthermore, despite CTV's dismal track record for dramatic programming historically, and the still-to-beproven results of their recent acquisition by Bell Globemedia, the Commission applauded CTV's programming lineup and imposed the same minimal requirement with respect to the exhibition of dramatic or long-form documentary programming as Global (ibid). 
CHAPTER THREE - The History and Structure of Organized Labour in the Canadian English Independent Film and Television Production Sector

Before the unions' policy interventions with the 1999 Television Policy and the decline in dramatic programming are examined, I will establish the unions' position within the industry and their policy capacities. Labour's position within the Canadian film and television production sector is directly tied to the larger political and economic environment in which the industry operates. The chapter situates the industry and its workers within the current economic and political environment and examines the five national English film and television labour unions in terms of their history, organization and role within the industry, with a brief overview of the organizations' relationship to policy activity in general. I then apply Pross' framework to evaluate the degree to which the unions can be considered constituent interest groups in the Canadian broadcasting policy network.

Film and television workers in the new economy

The economic foundations in Canada, as in many other parts of the world, have shifted from manufacturing to knowledge based industries (often referred to as the 'knowledge economy' or the 'information age'). Knowledge based industries place high value on human resources as the source of their strength. Creativity within those human resources is witnessing a new status; creative people bring extensible benefits to specific organizations, entire sectors and even local economies as a whole ${ }^{8}$. Creative people carry with them both cultural and economic capital. 
The film and television industry requires a certain amount of technical infrastructure, but the real infrastructure lies in the professional experience and expertise of the human resources. Television and film production is at its core an imaginative, creative undertaking at all levels. Dramatic programming creative teams include the writer who creates the script; the director who envisages the overall look and sound of the project; the actors who bring life to the characters; the production designer, art, paint, carpentry, props and set decoration departments who provide the physical environments and visual palette; the hair, makeup and wardrobe departments who support the actors in shaping the characters; the director of photography, camerapersons, grips and lighting technicians who shape the light and actually undertake the filming proper; the special effects and computer generated imagery technicians who create spectacular events and imaginary characters; the editor who performs the assembly; and post production workers who painstakingly lay in sound effects, adjust the colour correction and mix the hundreds of elements to produce an end product that, in the case of episodic television, is viewed by audiences every week. The creative teams are supported by an extensive team of administrative professionals both in production and post production. An extensive network of vendors ranging from equipment and raw stock suppliers to caterers, hotels, florists and car rental agencies supports the industry as a whole?

Unionized workers do most domestic dramatic television production and almost all foreign service production in Canada. There are five national labour organizations that represent almost every worker category specific to the English 
independent film and television production sector: The Alliance of Canadian Cinema Television and Radio Artists (ACTRA), The Director's Guild of Canada (DGC), the Writers Guild of Canada (WGC), The Communication, Energy and Paperworkers Union (CEP) and the International Alliance of Theatrical Stage Employees, Moving Picture Technicians, Artists and Allied Crafts of the United States, Its Territories and Canada (IATSE). Collectively, the five national film and television unions represent over thirty thousand workers in the Canadian English independent film and television production sector. The unions generally work in a collaborative fashion; a fully unionized Canadian dramatic television series will regularly sign contracts with at least four, if not all five of the labour organizations on a single project. ${ }^{10}$ It is not unusual for a dramatic television series to directly employ seventy cast and core production crew, supported by upwards of fifteen post production workers who contribute to the production of one one-hour episode every ten working days (an average shooting schedule).

In 2003/2004, independent film and television production ${ }^{11}$ accounted for the largest share of the Canadian production industry, worth $\$ 3.88$ million or $79 \%$ of the total $\$ 4.92$ million in total production volume. There are two driving sectors to the independent film and television industry in Canada. Independent domestic production, or Canadian content ${ }^{12}$, represented $40 \%$ of total production volume in 2003/2004 (CFTPA 2005). Independent foreign service productions, defined as those film or video productions shot in Canada by foreign studios and independent producers, represented $39 \%$ of total production volume in $2003 / 2004^{13}$ (ibid). The 
historical presence of foreign, primarily American, productions on the industry landscape has impacted the development and structure of the industry as a whole. As early 1958 the Association of Motion Pictures and Laboratories of Canada was lobbying the Diefenbaker government for tax credit support for the U.S. television series being shot in Canada, recognizing the significant economic contribution the foreign producers were making to the Canadian film and television industry (Dorland 1998). U.S. producers were initially attracted to Canada in hopes of bypassing the fifteen percent importation limit on foreign programming on British television by setting up Canadian subsidiaries and claiming commonwealth status (ibid). The first tax incentive program for producers of film and television product was introduced with the Capital Cost Allowance in 1974, designed to stimulate private investment in Canadian feature film. In 1997, the federal government announced the Production Services Tax Credit, the first labour tax incentive program targeted specifically toward foreign film and television producers shooting on location in Canada (CAVCO 2005).

Foreign service work is clearly a significant contributor to the Canadian English independent film and television production sector. Indeed, some would argue problematically so, wherein this sector is considered a cornerstone despite factors preventing Canada from exerting any real control over the volume of work on an ongoing basis. Foreign service work provides economic boosts to local industry and contributes to the development of the industry infrastructure, particularly in major production centres such as Toronto, Vancouver and Montreal. Foreign service work serves as excellent training grounds for Canadian creative and technical crews, and 
as many American productions have budgets that dwarf those of domestic projects, often allows for greatly expanded creative opportunities and access to new technology.

Complementary to trade liberalization under the paradigm of globalization is highly mobile capital and industry, and the film and television industry is by no means exempt from these challenges. While the Canadian dollar continues to operate at a favourable exchange rate to the U.S. dollar, the exchange margin has been unstable and generally shrinking in recent years as a result of the declining American currency. Current film and television tax credits continue to operate, with a federally administered baseline program complemented by additional provincial incentives. However, both of these factors lose their power in the context of a globalized industry. Other parts of the globe are competing for the lucrative U.S. foreign service sector, offering exchange rates comparable to, or in many cases better than, the Canadian dollar. Australia, Ireland, Romania, New Zealand and the Czech Republic are stimulating their film and television service industries through building infrastructure and attractive tax credit structures that foreign studios, with their eye on the bottom line, find increasingly appealing (Ernst \& Young 2004).

It is not only the migration of the film industry to distant foreign service areas that poses challenges to Canada's film and television industry. The issue of runaway production, wherein U.S. labour groups charge Canada with, 'stealing jobs that belong in the US' has sparked debate and a wave of incentives within the US itself in an attempt by politicians to stimulate their domestic production levels. States including New Mexico, Louisiana, Hawaii, Illinois, Pennsylvania, New Jersey, South . 
Carolina and New York have all recently released new tax credit and incentive programs designed to stimulate local production levels (Ontario PC 2004).

What Canada continues to hold as leverage in this highly competitive environment is the human quotient. Canadian crews are now regarded as some of the most professional and highly skilled in the world. The DGC and IATSE are regularly and routinely contracted on American productions to provide key creative, logistical and technical personnel with full complements of Canadian workers in each category. Only very few foreign workers are brought in to replace Canadian positions in these jurisdictions, and generally only those key creative positions attached to the financing of a project, such as a director, production designer or cinematographer. However, foreign service work does not benefit all unionized Canadian film and television workers equally.

ACTRA, the WGC and CEP do not fare quite as well in having their members employed on foreign service productions. Very often, the shows are written in the U.S. under Writers Guild of America contracts, and no WGC members are employed whatsoever. U.S. shows often come with principal or ensemble cast members attached. While ACTRA must grant permits for non-ACTRA members to work in their jurisdiction, and productions must agree to hire ACTRA members for any day players, minor roles and background performers, ACTRA is often under immense pressure to cede to U.S. cast demands from producers and other labour organizations in the interest of the industry as a whole. As a result of IATSE's strong presence in the U.S. and deeply developed relationship with many of the major studios, IATSE has generally benefited more from American service work than CEP locals. 
The domestic sector is thus a vital source of employment for many Canadian film and television industry workers. The domestic production base is required in order to provide stability where globalization leaves the foreign service sector highly volatile. On cultural terms, domestic productions are the only truly Canadian creative space, where total creative control remains in the hands of Canadians. When the Canadian Audio Visual Certificate Office (CAVCO) and the CRTC determine Canadian content through their points systems, the actual content of the project is not taken into account. What is taken into account are the key creative personnel who create, shape and bring life to the content - the writer, director, lead performers, director of photography, art director, composer, and picture editor. It is the workers themselves who define Canadian content.

The individual unions as labour groups

With one exception, the five labour organizations that are the focus of this analysis are exclusively Canadian in their structure and jurisdiction. Their histories are varied, ranging from over a century of organizing in Canada to just over a decade. Their organizational philosophies toward and approaches to public policy issues further reflects the heterogeneity of these five unions.

\section{DGC - The DIRECTOR'S GUILD OF CANADA History and structure}

The Director's Guild of Canada was founded in 1962 with a total membership of eighteen film directors. At present, the DGC represents over three thousand seven hundred key creative and logistical personnel in the Canadian film and television 
industry. Nationally, the DGC represents Directors, Assistant Directors, Location Managers, Production Designers, Production Managers, Editors and Accountants. The Director's Guild also represents other categories regionally, such as Production Coordinators in Alberta and Locations Security in Ontario.

The DGC is nationally constituted through the National Executive Board comprised of a National President, National Vice-President, a Second National VicePresident and a National Secretary-Treasurer. Seven regional chairs, one each from the District Council Offices of British Columbia, Alberta, Saskatchewan, Manitoba, Ontario, Quebec and Atlantic Region also on the National Board, as do seven Caucus Representatives from the Director, Assistant Director, Production Manager, Location Manager, Art Department, Editing and Accounting categories representing worker categories. (DGC 2004).

As the governing body of the Director's Guild, the National Executive Board is responsible for membership; negotiation of all director's agreements; administration of benefits plans; communication with members, the media and the government on all national and international issues; acting as a resource and information centre for the District Council Offices; forming national and international alliances; and represents the DGC on all national and international policy issues (DGC 2003).

The national office works under the stewardship of the National Executive Board. The DGC's national office is located in Toronto, and the National Executive Director/CEO oversees the day to day activities of the DGC. The Executive Director supervises eight staff responsible for membership, finance, rights collectives and affairs, communications, research and policy, and systems administrations 
departments. The Executive Director is deeply involved in all the Director's Guild's policy activities, supervising research, bringing policy issues and concerns to the attention of the National Executive Board and representing the DGC in policy interventions, often in conjunction with the National President.

The District Councils perform more administrative functions in upholding the national mandate, such as negotiating and administering regional collective agreements, implementing permit policies, procurement of production, promoting and marketing members and acting as an industry resource for producers. District Councils also play an increasing role in local and provincial policy matters, and lobbying and joint political action within their specific jurisdiction falls within their list of responsibilities (DGC 2004).

The national office has a long list of affiliations and partnerships, one indicator of political activity and networking. At present, the Director's Guild of Canada is currently affiliated with the Actors Fund of Canada, International Association of Audiovisual Writers and Directors, Canadian Film Centre - DGC scholarship, Coalition Against Satellite Signal Theft, Coalition for Cultural Diversity, Directors Rights Collective of Canada, International Forum of Directors Organizations, Union Network International/Media Entertainment International, International Standard Audiovisual Number, Coalition of Canadian Audio-Visual Unions, Canadian Television Fund Renewal Coalition, and the Canadian Film and Television Industry Council. 


\section{Political and policy engagement}

Policy development, advocacy and intervention are central to the DGC's national operations. Early lobbying efforts in the sixties focused on the development of state financial support for the feature film industry. By the seventies, lobbying efforts had expanded to television broadcasting and engaged with Canadian content quotas. The economic impact of the recession of the nineties re-stimulated the DGC's participation as policy actors, and they have since been pressuring the federal government for improved fiscal and regulatory support for the Canadian film and television industry (DGC 2004a).

Policy is written into the very fabric of the DGC's constitution.

Article $2.023(h)$ lists one of the objectives of the organization as, "to lobby for, encourage, advocate, advance and secure appropriate legislation, regulation, public policy and other government action to advance the welfare and interest of its members" (DGC 2003). A key focus of theirs is to operate as, "a visionary leader and partner in the development of the international Canadian film and television industry at a policy and professional level" (DGC 2000). Currently, the DGC is involved with policy issues related to international co-productions, feature film policy, the Canadian Television Fund, Canadian dramatic programming, cultural diversity and copyright. The DGC has also filed numerous CRTC interventions over the years, recently addressing issues related to foreign satellite service, nonCanadian third language digital television and broadcasting ownership. 


\section{ACTRA - The Alliance of Canadian Cinema Television and Radio Artists History and structure}

ACTRA represents eighteen thousand on and off screen performers in film, television and video in Canada. Worker categories specific to English independent film and television production include actors, announcers, background performers, choreographers, dancers, singers, models, hosts, narrators, commentators, stunt performers, puppeteers and vocal or dialogue coaches (ACTRA 2002). ACTRA's history dates back to the very beginnings of performer organizing in Canada with its roots in the Radio Artists of Toronto Society (RATS) in the early forties. In 1943 the group expanded into a national coalition of performer groups, becoming the Association of Canadian Radio Artists. In 1984, three existing guilds - the Association of Canadian Television and Radio Artists (ACTRA) Media Guild, the ACTRA Performer's Guild and the Writers Guild of Canada finalized a merger and officially became ACTRA- the Alliance of Canadian Cinema, Television and Radio Artists. The merger of the three parties did not last long - the writers left in 1993 to re-form the Writers Guild of Canada, and the ACTRA Media Guild membership lost its jurisdiction over freelance broadcasters at the CBC. The ACTRA Performers Guild restructured and took sole ownership of the ACTRA acronym (ACTRA 2004).

Two bodies, the National Council and the National Executive, govern ACTRA national. The ACTRA National Council has twenty-four general members from the branch offices, one each from Newfoundland, the Maritimes, Ottawa, Winnipeg, Saskatchewan, Calgary and Edmonton, two from Montreal, three from Vancouver and twelve from Toronto. The National Council elects the National Executive, comprised of the President, Vice President, Treasurer and four Executive Members. 
The National Council is responsible for developing national bargaining objectives and all matters arising from collective agreements; overseeing all committee work' approving the budget; developing and implementing public policy objectives; international relations; and convening the annual general meeting.

The National Executive, with the support of ACTRA National staff, is responsible for the business and financial administration of the National office, located in Toronto. The National Executive is also directly responsible for overseeing three key areas of ACTRA's operations: The ACTRA Performer's Rights Society, a subsidiary that was incorporated in 1984 as a non-profit organization to oversee performers royalties, fees, and other performance or tariffs entitled to members under the Copyright Act; Face To Face, the national promotional publication and website for ACTRA members; and the ACTRA Fraternal Benefit Society, which administers the national benefits plan (ibid).

ACTRA has significant staff support in running the organization. The National Executive Director is supported by three senior staff - the National Director of Finance and Administration, the Regional Executive Director and the Director of the Performer's Rights Society, who in turn supervise their own team of administrative and support staff - in overseeing all elements of business operations, including Collective Agreements, Public Policy and Communications, Finance and Administration, and IT divisions.

ACTRA is affiliated with the Canadian Labour Congress and the International Federation of Actors, as well as the Coalition of Canadian Audio-Visual Unions and the Canadian Film and Television Industry Council. Most recently and significant in 
examining ACTRA's activity in the policy arena, ACTRA has announced a strategic alliance with the United Steelworkers in addressing cultural issues on a joint basis. With the United Steelworkers representing 255,000 workers across Canada in various employment sectors, this affiliation adds substantial support and credibility to future political endeavours on ACTRA's behalf.

\section{Political and policy engagement}

Involvement in public policy is entrenched within ACTRA's organizational philosophy. One of the constitutionally stated responsibilities of the National Council is to develop and promote public policy objectives (ACTRA 2003). Further to this end, the National Office has devoted considerable resources specifically to public policy. ACTRA (as it was then constituted) was involved in the development of Canadian content regulations for radio, and throughout the 1960 s was a strong proponent of increased, long term, stable state funding for the Canadian film and television industry. ACTRA was a major supporter in the development of the Canadian Film Development Corporation (now Telefilm Canada) and in the early 1970 s were consulted in the development of the system devised to determine eligibility for the feature film Capital Cost Allowance tax program. ACTRA has been involved in amendments to the Copyright ACt, and ACTRA member and GeneralSecretary from 1965 to 1986 , Paul Siren, co-chaired Canada's delegations to UNESCO meetings that resulted in the Declaration on the Status of the Artist in 1980. Paul Siren subsequently went on to chair a federal task force whose recommendations resulted in Canada's Status of the Artist Act in 1992. ACTRA has appeared before 
multiple Standing Committees and the CRTC on numerous occasions. Recent policy activity engages with issues concerning cultural diversity, non-Canadian third language digital services, broadcasting ownership and most prominently their, "Campaign for Canadian programming" which focuses on increasing the production and broadcast of Canadian dramatic programming.

\section{CEP - The COMMUNICATION, ENERGY AND PAPERWORKERS UNION History and structure}

The Communication, Energy and Paperworkers Union was formed in 1992 through the merger of the Canadian Paperworkers Union, the Communications and Electrical Workers of Canada, and the Chemical Workers Union. The CEP is the third largest private sector union in Canada with a total membership of over one hundred and fifty thousand. It is Canada's largest media union representing over twenty thousand workers in the film, television, radio, magazine, book publishing and new media industries (CEP 2004). The CEP represents approximately two thousand technicians from the English independent film and television production sector through locals NABET 700 in Toronto and ACFC West 2020 in Vancouver. ${ }^{14}$

The CEP operates through its National Executive Board which is elected every two years. The National Executive Board consists of the President, SecretaryTreasurer, Executive Vice President - Quebec, Vice President - Media, six General Vice Presidents and six Administrative Vice Presidents. The Vice Presidents act as representatives of the CEP's regional offices operating in Calgary, Dawson Creek, Moncton, Montreal, Thunder Bay, Toronto and Vancouver. The National Executive Board also includes seventeen rank-and-file members, four each from Quebec, 
Ontario, Western Canada and the Atlantic Region, as well as a People of Colour/Aboriginal Peoples representative (CEP 2002). The National Executive Board meets three times per year and is responsible for overseeing organizing, publicity, education and research projects. The Board also approves strikes and administers financial and other assistance to locals as required.

Significant staff resources for national activities support the National Office located in Ottawa. There are three main divisions within the National Office. The President's office oversees education, human rights, job evaluation, research, communication and website activities. The Secretary Treasurer's office is responsible for dues, membership, accounting, payroll, accounts payable, inventory and technical matters. The Media Division, overseen by the Vice President - Media, is engaged with all matters relating to the twenty-thousand media workers the CEP represents, including pursing organizing, initiating programs and policies as related to the media sector and presiding over Media Sector Council meetings and elections. The Vice President - Media also acts as the CEP spokesperson to the public, media and government on media-related issues (ibid).

Local autonomy is central to the organization and political structure of the CEP. While adhering to the national constitution, programs and policies, each local is responsible for all its own affairs, including membership, dues, executive structure and elections, training, communication and political activity. The National Office provides support in locals' endeavours that work toward national objectives, such as policy advocacy. Each local negotiates its own collective agreement, although all contracts must be ratified through the National Office. 
The CEP has a long list of affiliates and partnerships. Those relevant to their media and policy activities include the Independent Broadcast Locals Council, the National Alliance of Communications Unions, Union Network International, the International Federation of Journalists, the Canadian Centre for Policy Alternatives, the Canadian Association of Labour Media, the Canadian Coalition of Audio-visual Unions and the Canadian Film and Television Industry Council (CEP 2004).

\section{Political and policy engagement}

Political activism and policy intervention are central to the CEP's operations. One of their stated constitutional objectives is, "to assist in advancing the social, economic and general welfare of working people through political, educational, civic and other activities," as well as, "to engage in political activities to secure beneficial legislation and obtain the defeat and repeal of harmful legislation" (CEP $20022.01 .04,2.01 .06)$. The CEP adopted its first official media policy at the 2004 National Convention. Echoing some of the foundational principles of the Broadcasting Act, the driving philosophy behind the policy is that, "Canadian media must be accessible, diverse, accountable and offer a safe and rewarding workplace" (CEP 2004, Executive Summary). The CEP has engaged with issues surrounding media concentration, foreign ownership, convergence, media democracy, the Canadian Television Fund, Canadian dramatic programming, funding for the $\mathrm{CBC}$, and cultural sovereignty and international trade. 
IATSE - The International Alliance of Theatrical Stage Employees, Moving Picture Technicians, Artists and Allied Crafts of the United States, Its Territories and Canada

History and structure

IATSE is the oldest of the labour organizations representing film and television workers in Canada. It is also the only labour organization in this study that is not entirely Canadian in its structure and governance. Formed in 1893 with a local in New York City, IATSE admitted its first two Canadian locals in 1899 - local 56 in Montreal and local 58 in Toronto - and in 1902 officially changed it name from the National Alliance to the International Alliance (IATSE 2004). The IATSE is still headquartered in New York, NY, with a west coast office in Toluca Lake, CA and the Canadian Office in Toronto, ON. Divided into thirteen districts, eleven across the U.S. and two in Canada, IATSE represents approximately one hundred thousand members in total, and fourteen thousand Canadian workers in animation, computer generated imagery, theatre, post production facilities, motion picture and television production, projectionists, theatre technicians and trade shows and exhibitions. Categories represented of the approximate ten thousand members specific to the Canadian independent film and television production sector include set decorators, scenic artists, painters, carpenters, grips, electricians, special effects technicians, props, hair, makeup, wardrobe, cinematographers and other audio visual technicians, transportation, sound technicians, script supervisors, craft service personnel and production coordinators. Across Canada, the category of workers represented by IATSE local varies by jurisdiction ${ }^{15}$. In some production centres in Canada IATSE technicians locals are in direct competition with CEP locals for 
contracts, such as IATSE Local 873 and NABET Local 700 CEP in Toronto, or IATSE 891 and ACFC West 2020 CEP in Vancouver.

The General Executive Board elected every three years governs IATSE. The General Executive includes the President, General-Secretary Treasurer, thirteen International Vice Presidents each representing a district, three International Trustees, two AFL-CIO delegates and one Canadian Labour Congress delegate. The General Executive Board meets at least twice per year and oversees the governance of the IATSE. They preside over the by-laws, act as an appellate tribunal for Presidential decisions, constitutional changes and amendments, and vote on policies and plans as determined by the President's office (IATSE 2001). The President wields considerable power in the IATSE, and in conjunction with the General-Secretary Treasurer oversees all day to day functions of the organization.

For administrative purposes, the IATSE International is divided into five divisions - Organizing, Stagecraft, Tradeshows, and Motion Picture and Television Production for the U.S. jurisdictions, and the Canadian Affairs Office for all Canadian locals (ibid). There are forty locals across Canada, divided into two districts. District Eleven covers all of Canada east of and including Ontario, and District twelve covers the provinces west of Ontario. District conventions are held at least every two years, and a Canadian convention is held on an annual basis. The Canadian office, run by the Director of Canadian Affairs and one support staff, is responsible for overseeing the activities of the four locals in Quebec, seventeen in Ontario, two in Manitoba, three in British Columbia, two each in Alberta, Saskatchewan, Nova Scotia, 
Newfoundland and Prince Edward Island, and four locals whose jurisdiction covers more than one province.

Similar to the CEP, local autonomy is the cornerstone of IATSE's organizational philosophy. Locals are responsible for their own internal executive and administrative structure, constitutions, membership and dues, training, education, collective agreements, benefits, partnerships, affiliations and labour negotiations within the binding rules of the International.

The only official affiliations IATSE shares are with the American Federation of Labour-CIO and the Canadian Labour Congress. The Canadian Office has just recently joined the Canadian Film and Television Industry Council.

\section{Political and policy engagement}

Unlike the other unions in this study, political action and policy intervention are not at the core of IATSE's activities in Canada. Despite their industrial strength and size, IATSE is primarily a wages-and-benefits organization in Canada. Only very recently have they made their first and only policy intervention as a national labour organization with their submission to the Standing Committee on Canadian Heritage's Feature Film Policy Review. IATSE's absence in the development of Canadian broadcasting or any other Canadian cultural policy will be further explored within this analysis in determining contributing factors to IATSE's lack of participation in the policy arena. 


\section{WGC - The Writers Guild of Canada History and structure}

The Writers Guild of Canada is a national association representing more than one thousand eight hundred screenwriters working in film, television, radio and multimedia production in Canada. The WGC has been in existence in Canada for approximately forty years, starting off as an association of radio writers with the CBC. Evolving with the development of the Canadian film and television industry, the WGC partnered with the ACTRA Performers' Guild, working as an informal coalition until 1984 when the ACTRA Media Guild, ACTRA Performer's Guild and the Writers Guild of Canada finalized a merger and officially became ACTRA. As noted earlier, the merger was not to last long and by 1993 , with the membership of the WGC growing and concerns increasingly differing from those of the other members, the Writers Guild broke away to re-form an independent labour organization. Writers Guild members work on dramatic TV series, movies of the week, feature films, miniseries, documentaries, animation, comedy and variety series, children's and educational programming, radio drama, as well as corporate videos and multimedia productions (WGC 2004). The WGC has only one office, located in Toronto. Holding elections every two years, the WGC is governed by a seven member National Council, with regional interests represented by the National Forum with fifteen members from the five district regions across Canada (Atlantic, Quebec, Central, Western and Pacific) ${ }^{16}$. The National Council is responsible for overseeing all Guild activities and setting policies. The National Forum meets annually with the National Council to discuss issues of national and regional concern. 
Overseeing all aspects of the WGC's daily operations, the Executive Director is supported by senior staff supervising industrial relations, communications, member and information services, finance, agreement administration and policy. The Executive Director, supported by the Director of Policy, is the public face of the WGC, signing all policy correspondence and appearing as the WGC representative in policy advocacy.

In addition to membership in the International Affiliation of Writers Guilds, other affiliations include membership in the Coalition of Canadian Audio-visual Unions, the Canadian Film and Television Industry Council, and the Coalition for Cultural Diversity.

\section{Political and policy engagement}

As a strictly national organization with no district offices, the WGC is primarily and deeply involved in policy issues at the federal level. Their quarterly publication of Canadian Screenwriter details policy issues and actions taken by the WGC. Their sole focus in lobbying is on the domestic film and television industry, as writers rarely undertake work on foreign service productions. Recent lobbying efforts have focused on increased development money for writers resulting in the creation of Telefilm Canada's Screenwriting Assistance Program, lobbying for revisions to Canadian content regulations to require Canadian writers as a mandatory component for qualification under both Canadian Audio-Visual Certificate Office (CAVCO) and CRTC systems, long term stable funding for the CBC and the Canadian Television Fund, increased funding for development of Canadian feature films and 
most prominently, a directed lobbying campaign for an increase in Canadian English dramatic programming.

The unions as constituent interest groups within the policy network

A basic structural framework and brief introduction to the policy activities of the labour organizations has been provided as a point of entry for more in-depth analysis of labour's involvement in the Canadian broadcasting policy network. Pross' model will now be applied in evaluating labour's status as members of the policy network. Analysis will first focus on answering the four questions derived from Pross' framework for determining whether a group can be classified as a constituent interest group:

1. Are they organized in a formal capacity?

2. How able are they to aggregate and articulate common interests?

3. Do they exhibit a desire to influence the government rather than be the government?

4. Do they try to persuade the Canadian federal government to pursue the policies they advocate?

Degree of organization conducive to policy advocacy

By their very nature as labour representatives, the unions have at least some basic infrastructure and organizational capacity. What requires examination is the degree to which the infrastructure and organization of the unions' influences their capacity to act in the policy sphere.

The CEP and DGC both use Executive staff as their policy spokespersons. While policy is certainly a primary activity for the VP - Media at the CEP, and CEO and Executive Director of the DGC, it is not their sole responsibility. Both ACTRA and 
the WGC have dedicated policy staff - ACTRA has a Director of Policy and Communications, and the WGC made a point of formalizing the importance of policy within their staff structure with the position of Director of Policy almost immediately after their break from ACTRA in the early nineties. ACTRA has only recently hired a full time policy staff member, but has hired policy experts as required for decades. IATSE's Canadian Office, with extremely limited staff resources and little policy expertise, is the most impoverished in terms of its policy resources.

All unions share a level of national organization, but to varying degrees. The WGC is strictly a national organization, with only one office, whereas the DGC and ACTRA national offices operate as national information clearing and administrative houses for their regional offices, each of which share a solid relationship with each other through the national office. The CEP and IATSE share organizational structures similar to each other, with a fairly decentralized organizational philosophy and heavy emphasis on local autonomy. For these two organizations, the national office serves primarily as supervisor and reporting centre for the autonomous independent locals. The level of national organization impacts their ability to communicate with their members and, in turn, ability to develop organizational policy positions.

\section{Aggregation and articulation of policy positions}

IATSE's organizational structure has a great deal to do with their difficulty in articulating and aggregating a common interest into a policy document or platform. With no staff expertise in the policy arena, no formal communications structure 
between the Canadian office and the locals, or between the locals themselves on issues specific to the Canadian film and television industry, it is extremely difficult to come to a policy position that reflects the needs and interests and is endorsed by the membership. Unlike ACTRA, the DGC, WGC and CEP that have established communication structures such as national newsletters, magazines, websites and political committees that allow the membership and national governing body and staff to communicate with each other, IATSE is only in the earliest stages of developing such channels. The only publication issued to the entire Canadian membership is the "Bulletin" a magazine published quarterly by IATSE headquarters in New York. Covering all jurisdictions, and with a decided American bias in content, there is little or no emphasis on policy concerns specific to the Canadian film and television industry. The Canadian locals only convene once a year at their annual Canadian convention, providing limited opportunities for development of a national dialogue on issues facing the industry. In January 2005, the IATSE Canadian Office sent out the first policy memo to Canadian locals asking for their perspective on developing a policy position for the Standing Committee's Feature Film Policy Review. Due to the decentralized nature of the organization, articulation of a policy position on any or all of the issues currently facing Canadian broadcasting could take considerable time. Furthermore, IATSE describes itself primarily as an industrial rather than cultural union, with a strong focus on economics rather than cultural benefits or the public interest at the centre of its philosophy. As IATSE does relatively little Canadian domestic production, member or national interest in 
engaging with the issue of dramatic programming or related matters could be difficult both to measure and to muster.

The CEP is in a unique position in terms of their structural organization and ability to articulate and aggregate their interests. Unlike ACTRA, DGC, WGC and IATSE, the CEP does not have a straightforward relationship to the Canadian film and television production industry. While the CEP represents approximately two thousand members in the independent production sector, the broadcasters, whom have been the subject of much of the unions' political scrutiny of late, directly employ many of the CEP's twenty thousand media workers. As such, the CEP keeps an arms length relationship to financing policy lobbying efforts, providing expertise and political clout as a national representative of 150,000 Canadian workers, but allowing the locals directly involved with the English independent film and television production sector (in this case NABET 700) to provide financial contributions to specific research and lobbying campaigns ${ }^{17}$. That said, the CEP has clearly articulated their policy positions in their 2004 Media Policy, complied through elected committees of members from the media sector, approved by the media council and voted on by all members at the 2004 national convention. The committees commissioned and performed in-house research in compiling the comprehensive document covering all areas of Canadian media. In contrast to IATSE, the CEP considers itself to be a "proudly Canadian union" that is concerned with issues that reach far beyond those of wages and benefits (Murdoch 2005). The CEP described one of the functions of their lobbying efforts to be trying to articulate 
what is in the public interest, laying down in policy and regulation not just what is good for the membership, but what is good for the country as a whole (ibid).

ACTRA, the WGC and the DGC all share similar structural characteristics that facilitate communication between members and the national office. As mentioned, both ACTRA and the WGC have dedicated staff who research and identify current issues in the policy arena, whereas that role falls to the Executive Director/CEO at the DGC. The Writers Guild, with a relatively small membership and no branch or district offices, communicates directly with all its members in a national capacity. Both ACTRA and the DGC have lively regional structures that allow members to engage both with issues specific to their own community (for the regional concerns in a major production centre such as Vancouver are not the same as those in Regina) as well as those political issues that face the membership on a national level. All three organizations publish regular magazines/newsletters in which a portion of the content is devoted to policy issues. All three also operate websites on which there is full access to policy submissions and position papers, as well as background and historical information on the issues and the organization's relationship to them as film and television labour representatives.

ACTRA uses a variety of formal committees, such as education, political action, priorities and planning, and equal opportunity committees in the development of policy positions in ensuring member support for policy initiatives. The WGC also uses member committees in a similar capacity, but does so in a less formal, more ad-hoc and issue based manner. For example, the WGC recently convened a panel of their top feature film writers to assist in the formation of their 
submission to the recent Standing Committee on Canadian Heritage's review of feature film policy (Martiri 2005). As all three organizations deal exclusively with the motion picture and related media industries, (unlike IATSE who also represents theatre and trade show technicians and projectionists, or the CEP whose membership is hugely varied and includes forestry workers for example) the national infrastructure and communication channels for ACTRA, the DGC and WGC concentrate all their efforts on a relatively focused policy sphere and endeavour to draw on the engagement of their entire membership in developing their respective. positions.

The ideological standpoints from which these three organizations derive their policy positions varies slightly. While ACTRA policy documents would indicate a deep-seated commitment to Canadian cultural development, no mention was made of this as an overarching objective in an interview with the Director of Public Policy and Communications. The primary stated reason for engagement in policy and the dramatic programming issues in particular was employment for the membership, as ACTRA's primary objective in policy interventions is to, "to ensure it's viable to make a living as a performer in Canada" (ibid). ACTRA will, on occasion, position itself as representing Canadian interests, as in the case of the full page advertisement that was taken out in the Hill Times charging the Canadian Association of Broadcasters with putting their own needs before those of Canadians (Thompson 2005).

The WGC holds cultural expression and representation at the core of their organizational and policy philosophies as a labour organization. The WGC argues that 
the writers who choose to remain in Canada (rather than forging a living south of the border) are committed to the ideals of Canadian culture and the right to Canadian cultural expression and storytelling, not just the right to make a living as a writer in Canada, and that this commitment is reflected in the WGC's policy positions on the value of Canadian creative works.

The DGC is affiliated with internationally active organizations committed to general principles concerning cultural sovereignty, cultural diversity and creative rights, including the Coalition for Cultural Diversity, an organization dedicated to keeping culture off the trade table at the World Trade Organization, of which the DGC was a founding member ${ }^{18}$. While participation and defense of the domestic industry and promotion of cultural sovereignty with regard to cultural policy design and implementation will ultimately prove beneficial for the employment levels of the DGC's constituency, it also indicates a commitment to issues that affect citizens outside the membership and industry, evidencing an engagement with matters that may be seen to work toward the broader public interest as a whole.

\section{Relationship to the government}

Pross' third characteristic requires that groups exhibit the desire to influence the government rather than be the government. All the unions are still primarily organizations dedicated to ensuring basic working conditions and promoting the interests of their members within a specific sector of the labour force. While lobbying activities are central to some, and less so to others, their primary responsibility still lies in the "wages and benefits" aspect of their constitutive 
beginnings. However, as the unions evolve as members of the policy community, employing more effective and sophisticated strategies in their networked capacity, they also express desires to further their positionality, power and influence within the policy network. ACTRA, the DGC, the WGC and the CEP are currently lobbying for creator representation on the Board of the Canadian Television Fund. The CTF Board is a mix of public and private sector representatives, with fourteen of the nineteen seats allotted to private sector members of the film and television industry. Those same unions have also pressured for representation on the Feature Film Advisory Board, which at present has eleven of the thirteen seats held by executives from the motion picture production and distribution sectors. Closer to the actual regulatory power centre, these unions have also expressed an interest in seeing creative representation at the CRTC itself, noting that several appointments are imminent. In evaluating this next to Pross' characteristics, the small (if any at all) voice of union executives or members in any of these structures would not yield enough power or influence to be considered a desire to become the government itself. Rather, it should be taken as a desire to balance the perspective within government apparati that have been structured in a way that could be perceived as privileging a corporate or market approach to cultural activity.

With three of the four of Pross' characteristics examined, the disparity between the unions becomes evident. The unions have varying levels of organizational policy capacity and ability to formulate policy positions and exhibit the desire to influence rather than be the government. Next I will examine if and how the labour organizations try to persuade the government to pursue the policies 
they advocate. The case study for this analysis will be the unions' involvement with the CRTC's 1999 Television Policy and Canadian dramatic programming. 


\section{CHAPTER FOUR - The Unions' Engagement with the CRTC over the 1999 Television}

\section{Policy and the Issue of Canadian Dramatic Programming}

Pross identifies four functions for groups within a policy network. Their capacity to communicate, administer, regulate and, in the process, legitimate that state affects their value, power and influence within the policy network. In adding to the model, I argue that a group's ability to challenge the state is also a fundamental aspect of network participation. This model will be applied in evaluating the unions' efficacy within the Canadian broadcasting policy network around the issue of dramatic programming. Analysis reveals how their arguments and strategies have evolved since 1998 in persuading the government to adopt the policies they advocate.

\section{Development of the 1999 Television Policy}

ACTRA, the DGC, the WGC and CEP were all involved in the public consultation process that lead to the formation of the 1999 Television Policy. The DGC appeared at public hearings with Executive Director Pamela Brand, National President Allan King and regulatory legal expert Peter Grant to speak to their written submission, calling clearly for the CRTC to exercise all the regulatory tools in its policy kit to increase both broadcaster financing and scheduling of first-run Canadian entertainment programming (drama, variety, children's, music, and dance programs) in prime time (CRTC 1998). Maureen Parker, Executive Director, Robert Geoffrion, Treasurer and Screenwriter and Jim McKee, Director of Policy and Communications represented the WGC. Their proposal included financing minimums 
for programming development set as Conditions of Licence for the broadcasters upon licence renewal, a change to the CRTC's points system for determining Canadian content eligibility wherein a Canadian writer would be a required rather than an optional component, and a request to raise the minimum points required to qualify as Canadian content from six out of ten to eight out of ten under CRTC regulations ${ }^{19}$ (CRTC 1998a). The beginnings of cohesion between labour organizations were evidenced when the WGC stated their support for the DGC's proposal, but did not go into great deal in that regard, focusing primarily on issues specific to writers. ACTRA National President Brian Gromoff and Policy Advisor Garry Neil appeared before the commission, also supporting the DGC's proposal to increase financing and scheduling of Canadian entertainment programming, but further muddied the voice of labour by proposing a different change to the points system from that of the WGC. ACTRA's revision would award two points for the lead performer and one each for the second and third if Canadian, as well as increase the minimum points to qualify as Canadian from six out of ten to ten out of twelve (CRTC 1998b).

The CEP took a major departure from the proposals of the other three organizations representing workers in the English independent production sector. Framing their proposal as a "business case," the CEP argued for increased broadcaster in-house production and broadcaster access to public funds through Telefilm and other initiatives. The CEP argued that if the broadcasters were allowed to own the Canadian content rather than just licence it, the ability for the broadcaster to "bicycle" the production through the broadcasting system would ultimately result in significantly increased profitability and thus increased desire to 
undertake more Canadian content programming, fulfilling both cultural and industrial objectives of the Broadcasting Act. Furthermore, once this system was in place, the CEP argued the CRTC could reasonably increase Canadian content minimum to $70 \%$ and still have broadcasters operate on a profitable basis (CRTC 1998c). With a relatively small proportion of their membership working in the independent production sector, the CEP did not feel this model would have an unduly negative impact on their membership, although they admitted to the Commission that they had not consulted with other members of the independent production sector prior to filing their submission (ibid).

IATSE made no submission or intervention at all with regard to the television policy review. For those who did, the tendency for each organization to put forth proposals that benefited their particular membership and conflicted or sidestepped those proposed by their labour colleagues would not serve any of the organizations well in the long run.

As noted, the release of the CRTC's 1999 Television Policy brought significant changes to the regulatory environment. Removal of expenditure requirements for broadcasters and expansion of the definition of priority programming were the results, with no changes to broadcaster in-house production emphasis, Canadian content qualifications, scheduling requirements, eligibility or funding access as requested by the various unions. As noted by the DGC, the CRTC's 1999 Television Policy was labour's biggest defeat in the policy arena.

The release and impact of the 1999 Television Policy had a significant impact on how the unions try to persuade the government to pursue the policies they 
advocate. Most striking is their adoption of a national, labour based coalition strategy, operating as the Coalition of Canadian of Audio-visual Unions (CCAU).

\section{Re-"grouping" in the after-effects: Formation of the CCAU}

The unions' new strategy fits clearly within what Sabatier (1991) terms an advocacy coalition framework. Under the emergent policy environment, the idea of the sectoral policy network has shifted toward issue networks, characterized by interest groups or advocacy coalitions that engage with specific concerns rather than the sector as a whole and composed of a network of groups that share a similar perspective or basic set of beliefs on an issue (Richardson 2000, Sabatier 1991).

It was the Writers Guild of Canada who first sounded the alarm bells on the industrial impact of the CRTC's 1999 Television Policy. Since the development of dramatic programming, and particularly series television, begins many months and even years before the engagement of professionals related to the production stage, writers were the first film and television workers to feel the impact of the new policy direction. The WGC immediately began to compile statistics from their database detailing the decline in dramatic production. They initiated discussion with other labour organizations almost immediately, although it would take several years before labour really coalesced around the issue in a cohesive manner.

Although the writers were the first to feel the industrial impact of the new policy direction, it was not long after that the effects were being felt by all workers involved with Canadian dramatic programming. As stated earlier, in 1999 the total number hours of Canadian drama broadcast were 753. By 2000, that number had 
dropped to 661.5, in 2001 it fell again to 587 and by 2002, the total number of hours of Canadian drama broadcast had fallen a total of 36\% to 486 (CCAU 2003). The drama issue provided a common starting point on which all the unions could agree to begin to articulate a united policy position. Qualification levels for Canadian content and the number of points assigned to actors or writers were no longer relevant discussion points if the genre itself was in jeopardy.

Accounts vary about the actual genesis of the CCAU. The VP-Media for the CEP reports that he noticed labour speaking as individual organizations at a government roundtable meeting in early 2002 and approached the DGC, suggesting a meeting to discuss their common concerns (Murdoch 2005). The WGC attended that initial meeting and then all subsequently approached ACTRA, eventually expanding the coalition to include the American Federation of Musicians and the French language counterparts in the film and television industry. According to the WGC, it was their policy position paper that was pitched to ACTRA and the DGC, who saw the immediate need to form a coalition and pool resources (Martiri 2005). There is general agreement amongst DGC, ACTRA, WGC and CEP that Heritage Minister Sheila Copps played a key role in the reformation of labour's strategy in the policy arena. It was with the encouragement and support of the Minister of Canadian Heritage that the unions began initial discussions in early 2002 on the value of pooling their resources and speaking with one cohesive voice to the government. The benefit to the state is clear - coalitions of the type such as the CCAU represent one stop shopping in policy consultations and assist the government in avoiding the process of 
having to decipher whose perspective most accurately reflects or works in the best interests of the labour sector as a whole.

Undertaking the advice of the Minister, and recognizing the potential to gain both power and influence in a coalition strategy, the WGC, CEP, ACTRA and DGC were instrumental in organizing what is now a broad based labour coalition of those organizations as well as the American Federation of Musicians (AFM-Canada) representing musicians; Unions des artistes (UDA) representing French speaking performers; Association des realisatueurs et realisatrice du Quebec (ARRQ) representing French language directors in Quebec; Syndicate des techniciennes et technicians du cinema et de la video du Quebec (STCVQ) representing private sector film and video technicians in Quebec; and Societe des auteurs de radio television et cinema (SARTeC) representing French language writers. Collectively this coalition makes claims to represent fifty thousand cultural artists in Canada's film and television industry. The Coalition is the first of its kind in Canada, and noteworthy both for its formation and its strategy ${ }^{20}$.

According to the DGC and the WGC, IATSE was invited to join the membership but declined. Other members suspect that it is IATSE's American affiliation that prevents them from participating in a coalition that is only concerned with Canadian dramatic programming and not the foreign service sector, or that since IATSE does so little domestic production, they have very little interest in putting time or energy into the issue. From IATSE's perspective, they have little interest in joining the CCAU, as the CCAU's arguments tend to rely heavily on cultural values and strong regulatory structures, whereas IATSE's focus lies more in business and economic 
models that do not necessarily include strong state intervention in the film and television industries. IATSE is wary of heavy reliance on government initiatives such as labour tax credits, arguing that in the face of a globally competitive industry, such programs may in fact operate to lower the real wages of workers. IATSE recognizes that domestic production levels have a much more significant impact on the members of the CCAU than most IATSE members working in the independent film and television production sector, and thus the CCAU views the issues facing the industry from a different perspective. However, the Director of Canadian Affairs considers the CCAU's focus on domestic production at the exclusion of the foreign service sector "myopic" (Lewis 2005).

In July of 2002, the CCAU released its first position paper and made its entrance onto the broadcasting policy landscape. One of their first objectives was to bring the issue of dramatic programming and their proposed solutions to the attention of both the government and the public. The individual unions had been hard at work publicizing the issue and drumming up support within their own membership. In June of 2002, ACTRA held its first ever policy conference and launched its, "Campaign for Canadian programming" described as a broad based effort to take a leadership role in reviving Canadian drama (Thompson 2004). In April that year, the WGC had met with CRTC Chair Charles Dalfen to discuss the drama issue, introducing proposed solutions that would become the framework for the CCAU's policy platform: re-establish expenditure requirements for broadcasters to produce 10-point drama, establish minimum requirements for the number of hours of drama broadcast and eliminate the $125 \%$ time credit for six point drama (White 
2002). The issue was receiving attention in the unions' regularly published magazines/newsletters to the membership, but had not been sufficiently addressed in either the public sphere or the policy community. Drawing attention to the issue in both arenas became a paramount focus of the CCAU as a new coalitioned force in the broadcasting policy network.

\section{Structure and strategy of the CCAU}

Before the actions of the CCAU are examined, it is important to provide some structural analysis of the Coalition itself. The CCAU is an ad-hoc coalition, with a loose structure of the VP - Media for the CEP and National Executive Director and CEO of the DGC as co-chairs. There is no formal meeting schedule, mandate, constitution, membership guidelines or financial structure. Very much in keeping with Sabatier's advocacy coalition framework, the CCAU describes themselves as an issue based coalition. At present, they are focused on Canadian dramatic programming and related issues ${ }^{21}$. All work by the CCAU is done collaboratively and in a consensus based model, although the different unions do play different roles within the coalition.

The Writers Guild has a sophisticated database system and is the source for much research material and statistical information related to the industry. As writers, they also draft many of the submissions the CCAU has made to various reporting bodies, ministerial offices and the CRTC. The DGC has the longest history with political lobbying in Ottawa, and does a great deal of the public consultations and direct lobbying efforts. The DGC also brought regulatory legal expert Peter 
Grant of the internationally recognized McCarthy Tetrault law firm to the table as an outside resource in research and legal affairs in shaping the CCAU's policy proposals. The CEP is relatively new to the table in terms of being involved in lobbying specifically for the independent film and television production sector, but has substantial experience in lobbying generally and, with the clout of representing one hundred and fifty thousand workers across Canada is "prepared to pound the table or the pavement" more vehemently than either the DGC or WGC (Murdoch 2005). ACTRA uses the public profile of its membership extensively in the promotion of its issues both inside and outside the CCAU. ACTRA recognizes that politicians are not immune to the cache of celebrity, and consistently engages high profile members to gather media attention in putting a public face on the issues. Politicians like to have their picture taken with high profile people, which is why ACTRA members such as Sara Polley, Gordon Pinsent, Rick Mercer and Paul Gross participate in committee hearings, lobby days and dinners with key cabinet ministers, agencies and critics in promoting their message. The members of ACTRA are considered ambassadors for political activity in this regard.

One of the keys to success for the CCAU has been consistency in their message. Members of the CCAU participate both as coalition members and individual unions in the policy process, but are careful to remain on message at all times. The WGC noted that close and constant communication and coordination between the members of the coalition is crucial when undertaking lobbying efforts, interventions, meetings and consultations. For example, the Writers Guild will schedule a meeting with the Chief of Staff for the Minister of Canadian Heritage. The WGC will alert the 
other coalition members to this meeting. The DGC will then schedule a meeting several weeks later to discuss the same topic. The process will be repeated subsequently by ACTRA and the CEP in driving the message home over a period of time.

Putting Drama on the Agenda - problems and solutions as identified by the CCAU The CCAU takes full credit for putting the issue of Canadian dramatic programming on the policy agenda. In October 2002 the CRTC commissioned former CTV President Trina McQueen to examine the issue of English Canadian dramatic programming. The CCAU filed a preliminary version of its second report (their first major research report), "The Crisis in Canadian Drama," with McQueen, and subsequently filed the final version at 140 pages directly with the Minister of Canadian Heritage. Taking as the central problematic for Canadian broadcasting the CRTC's 1999 Television Policy, the report evidenced the decline in dramatic programming, poor scheduling practices of the major broadcasters, an increase in the amount of priority programming other than drama, a decline in broadcaster expenditures on dramatic programming and compared the situation in Canada to other countries with a strong regulatory framework in place (CCAU 2003). The CCAU expanded in great detail upon the solutions proposed in their brief four-page introductory paper of the previous year, calling for public hearings on the issue, increased funding from both the state and broadcasters for the genre, reinstatement of broadcaster expenditure requirements, greater transparency in broadcaster 
reporting for scheduling practices, and introduction of an incentive package designed to encourage broadcasters to develop and schedule Canadian drama (ibid). McQueen's findings, released in 2003, cemented the issue on the broadcasting policy agenda as a high priority, supporting the arguments posited by the unions and essentially charging the current system as having failed in its goals to operate in the public interest. Furthermore, the report fully recognized the economics of Canadian dramatic programming and dismissed arguments based on a market rationale.

No broadcaster has ever made money on drama. It exists entirely and only because of political and regulatory will...it's hard to reconcile the reality of our viewing with the objectives of the Broadcasting Act...Drama is the most appealing form of television for most Canadians. If they are not watching Canadian drama, it is hard to see how the Act is being upheld (McQueen 2003: 10).

MCQueen recognized the significant contribution of the CCAU to the consultation process. MCQueen commended the CCAU for their submission, noting it was, "the most comprehensive and well researched submission I received. I was impressed by the submission, by my meeting with the group, and their determination to work fiercely to change the situation for drama. Many of their ideas are reflected in my recommendations" (McQueen 2003: 11). McQueen's recognition of the problem was further supported by the release of the Standing Committee on Canadian Heritage's 2003 major report on Canadian broadcasting. Taking the regulatory framework as key component in meeting the cultural and social objectives of the Canadian broadcasting system, "Our Cultural Sovereignty: The Second Century of Canadian Broadcasting" recommended a full review of the 1999 Television Policy with a focus on its implications for Canadian dramatic programming (Standing Committee 2003). The report noted the CCAU's work as a significant contributor to 
the identification of the implications of the 1999 Television Policy, and accurately representative of the views of a significant segment of the industry.

The Committee notes that the Coalition's submission to Ms. McQueen is important for two reasons. First, it shows the extent to which Canada's creators are - as a whole - deeply troubled by the impacts that they have felt in the short time since the introduction of CRTC's new television policy. Second, it highlights the need for more complete data on scheduling and exhibition (ibid: 172).

With multiple perspectives agreeing that the lack of drama was problematic for the Canadian public service broadcasting model, in September 2003 the CRTC issued a public call for comments on the issue (CRTC 2003). The CCAU filed a follow up report with the CRTC, "Addressing the Crisis in Canadian Drama," and began to articulate the need for a mix of regulatory and incentive programs to increase the amount, quality and financing of Canadian dramatic programming (CCAU 2003a). The CCAU filed a subsequent submission with the CRTC in response to their May 2004 call for comments on a proposed set of dramatic programming incentives designed to stimulate the production and scheduling of original Canadian dramatic programming (CRTC 2004). In this submission, the CCAU set forth a detailed and sophisticated combination of both regulations and incentives to assist the development and broadcast of Canadian drama (CCAU 2004). The emphasis, however, in dissenting to the incentive-only program proposed by the CRTC was on the importance of regulation. While working partially within the established policy paradigm that emphasized regulatory flexibility through recognizing the importance of a combination of incentives and regulations in addressing the issue, the CCAU was nonetheless quite clear in its argument that, "the airing of Canadian drama must be seen as a fundamental obligation of all free-to-air television broadcasters, and not 
simply something that they should be lured into doing. Regulation is by far the most effective tool to achieve results..." (ibid: 3). In November of 2004 the CRTC released its final version of the incentive package designed to, "increase the production and broadcast of, the viewing to, and the expenditures on high quality, original, English language Canadian drama programming" (CRTC 2004a: 1). While many of the incentive proposals the CCAU recommended as part of an incentive/regulatory mix were reflected in the new program, there was no change to the regulatory structure at all.

In June 2005, the CCAU released their second major research report, focusing on the future of the Canadian broadcasting system should the 1999 Television Policy remain in place. "The Need for a Regulatory Safety Net" is targeted at the CRTC who are readying for conventional broadcaster licence renewals in 2006. The report evidences that spending on Canadian drama by private broadcasters hit a seven year low in 2005 , down to $\$ 53.6$ million from $\$ 73.0$ million in 1998 (CCAU 2005). The report identifies two key components of the "regulatory safety net" required to improve the amount of dramatic programming. The first component is a minimum expenditure requirement of gross ad revenue to be spent on Canadian drama, and the second a requirement that each station group commission at least two hours of original 10-point Canadian drama per week (ibid). On the same day the CCAU released their report, Minister of Canadian Heritage Liza Frulla announced that the CRTC will begin reviewing the 1999 Television Policy prior to the upcoming broadcasters' licence renewals (Vamos 2005). 
It is thus clear that unions currently involved in policy activity meet the requirements to be considered constituent interest groups in the Canadian broadcasting policy network. ACTRA, the DGC, the WGC and the CEP all have organizational structures, dedicated resources and expertise that facilitate the aggregation and articulation of policy positions. These unions also exhibit a desire to influence rather than be the government, and attempt to persuade the government to adopt the policies they advocate. Although IATSE's status as a constituent interest group is questionable, due to their absence in the policy arena, the organization will continue to be analyzed alongside the other four in documenting and evaluating their plans and potential as active members of the policy network.

Evaluation of the unions through their capacity to contribute to the network Pross' model analyses the success of constituent interest groups through evaluating their ability to facilitate communication, regulation and administration of the policy sector that and notes that these activities ultimately work as a form of legitimation for the state. As noted, I will add a fifth function, wherein the ability of a group to effectively challenge the state will affect its position and influence within the policy network. Pross' model also substantiates arguments that the power distribution within the Canadian broadcast policy network does not operate in a zero sum equation, where the amount of power is finite and a net gain for one actor necessarily entails a net loss for another. Rather, the relationships between the unions and the state are reciprocal and additive in their ability to support and 
legitimate each other, potentially improving the status of both within the policy network.

\section{Function \# 1 - Communication}

First and perhaps most practical of the functions, particularly for the unions of this study, is their ability to communicate with the state. Pross (1992) notes that groups communicate demands from their concerned publics (such as the unions membership) and at times from the broader public spheres to the state, and vice versa. Groups also serve the function of communicating information between government agencies and departments, and between levels of government. Finally, groups communicate within the policy community. Do the unions fulfill this function?

Key to the unions' success as the CCAU in putting and keeping drama on the policy agenda has been coordination between the organizations, communicating strategic meetings and messages in an attempt to have their efforts received by the state and reinforced by their colleagues. Furthermore, most of the five unions have developed effective means by which they can aggregate their members' interests and express those to the state, and in return keep their members well informed of current events and state actions in the policy arena.

A key question in the determination of the unions' ability to effectively facilitate communication between the state and their members in promoting their policy positions is to examine with whom the unions communicate. With particular regard to the issue of dramatic programming, the unions' primary focus has been the CRTC. The arms-length agency considers the unions to be a crucial component to the 
public consultation process as industry stakeholders who provide the frontline perspective on how programming is made, confirming the unions' opinion that they play an important informational and educative role in their regular communications with the state. CRTC Chair Charles Dalfen has personally met with the CEP, ACTRA, the WGC and DGC both individually and collectively as the CCAU. Mr. Dalfen is the first CRTC Chair to address the unions directly, giving speeches to the ACTRA Toronto Plenary and the CEP Media Council Conference in 2003 (Dalfen 2002, 2003). The CCAU met with Charles Dalfen in mid 2004 to discuss the "do-ability" of their proposed solutions to the drama issue, an example of the informal consultation process that happens regularly between stakeholders and CRTC representatives, both staff and executive (Dalfen 2005).

One of the most important messages the CCAU sent was not only in the actual content of their papers, but moreover in the structure of the Coalition itself, indicating to the policy community that labour was becoming better organized. The CRTC recognizes this, noting that the formation of the CCAU allowed the unions to aggregate their resources and to better articulate their views to the arms-length agency (ibid). In a policy environment where technological innovation poses serious challenges for regulatory agencies such as the CRTC in keeping up with rapid new developments and accompanying issues, the role of non-state actors, such as the unions of study here, to inform, educate and, importantly, help the government prioritize issues is paramount. The unions framed the issue of the sharp decline in Canadian drama in the most urgent of terms with both cultural and industrial 
implications, and clearly played a central role in placing this issue squarely on the CRTC's agenda.

The industrial effects of a decline in dramatic programming, with particular regard to employment levels, are easily inferred. The CCAU argues that should the CRTC not enact regulatory measures to promote dramatic programming,

Our dramatic production sector will be lost; new talent will not develop; existing talent will either relocate in another jurisdiction where they can find work opportunities or change profession altogether to support themselves and their families. This will leave Canada lacking the experienced, professional talent pool to make television drama if the regulations change too far in the future (CCAU 2003a: 10).

Less tangible are the cultural implications of a decline in Canadian drama.

The decision on behalf of the members of the CCAU to invoke cultural objectives as a foundational framework in making the case for Canadian drama was intentional and strategic. Economic arguments have their limitations. Economic models apply to some programming formats, such as lifestyle programming, that provide a regular return on investment. As outlined earlier, Canadian drama rarely operates in a positive return scenario for the broadcasters, and thus is difficult to justify in an economic argument. Fundamentally, the CCAU rejects a market rationale to broadcasting policy based primarily on broadcaster profitability. As the both the WGC and DGC note, no one is interested in putting the broadcasters out of business, or severely hampering their ability to operate profitably. In invoking notions of the public interest at the core of the mandate of the CRTC and the Broadcasting Act, the CCAU argues that the broadcasters have a responsibility to operate in the public interest as private users of public airwaves, that not every activity a broadcaster undertakes can reasonably expect to be profitable, and that some types of 
programming, such as Canadian drama, have significant social and cultural benefits that override a market rationale. The CCAU extends the benefits of dramatic programming well beyond the bounds of employment for its combined membership to a tool of social cohesion and a vehicle for the development of national identity.

No other genre of programming has shown itself to have the sustained ability to capture the public imagination in the way that series drama does. It remains the most popular and compelling genre for conveying themes and experiences that resonate with all Canadians. And by expressing universal themes in stories reflecting daily life from all regions of the country, drama has the further ability to strengthen bonds among Canada's diverse peoples (CCAU 2002:2).

Dramatic programs are indeed the manner in which Canadians tell and share their stories with one another...Dramatic series bring the continued, familiar and powerful storylines and characters that Canadians love to watch. Movies of the week and mini-series allow Canadian television viewers to explore a broad range of programming genres, ideas and concepts (CCAU 2003a: 2).

...any suggestion that a drama expenditure requirement should not be imposed on broadcasters because, "Canadian drama is not profitable" needs to be firmly rejected. Not every activity of a broadcaster that operates in the public interest can be expected to be profitable. A requirement to support Canadian drama is of fundamental importance (CCAU 2003b: 8)

Canadian drama is critically important to the future of Canadian television...The production of Canadian drama is central to our cultural sovereignty (CCAU 2005: 4).

As policy actors who are seen as credible sources for reflecting the interests of the workers in Canada's film and television industry, as well as appealing to the mandate of the CRTC through invocation of the public interest, the unions' ability to communicate within the network and the outside public has positioned them as one of the policy actors in the network that the state considers necessary in conducting the business of broadcasting policy. 
The film and television industries are considered significant economic and employment drivers that rely heavily on the professional skill and expertise of human resources for success. It is thus in the best interests of the policy makers to take the concerns and issues of the hands-on, frontline workers into consideration in the development of policy for an industry that, like many others in a globalized environment, is highly mobile.

Unions also benefit from communicating with the state. The DGC, ACTRA and the WGC noted that they are now regularly consulted by senior bureaucrats and Minister's officials before issues are brought to the public, and the CRTC noted that they will meet with stakeholders, including the unions, in an informal capacity on a regular basis. Such interaction allows the unions to remain informed and current on happenings in the policy arena, allowing them sufficient time and knowledge to develop cohesive strategies and positions in time to address the issues in formal policy and/or public spheres.

\section{Functions \# 2 \& 3 - Regulations and Administration}

The second and third functions from Pross' model are that of regulation and administration. The CRTC employs self-regulation in several parts of the industry, in what could be viewed as a version of a new public management approach, or at very least a result of the limited resources and administrative capacity of the state's broadcasting regulatory agency. Some members of the broadcasting policy network, most specifically broadcasters, cable companies and specialty channels, are responsible for the self-regulation and administration of several areas of their 
business operations. Undertakings such as the Cultural Diversity Taskforce, the Canadian Broadcast Standards Council and the Cable Television Standards Council are examples of self-regulatory bodies that establish codes of conduct and best practices surrounding such issues as violence, gender representation, cultural diversity, ethics, and advertising to children. As many of the unions are relatively young members of the policy network, most particularly in their most effective capacity to date as the CCAU, they have not had much time or enough power within the network to be held responsible for any significant amount of regulation or administration. Yet as noted in the previous chapter, they have expressed a great deal of interest in having representation on industry boards such as the Canadian Television Fund and regulatory structures including the CRTC itself. It will be interesting to observe whether the unions succeed in embedding themselves within regulatory and administrative elements of the broadcasting system as their profile and power with the policy network improves.

\section{Functions \# 4 \& 5 - Legitimate and Challenge}

The basic framework of the CCAU'S argument, in recognizing the television industry as an industrial and economic driver but relying heavily on cultural considerations to promote its objectives concerning dramatic programming, reveals how the unions perform the functions of both legitimating and, in adding to Pross' model, challenging the state as members of the broadcasting policy network.

By placing regulation at the centre of the solution in increasing the production and scheduling of original Canadian dramatic programming, the CCAU 
legitimates the role of the regulatory agency within the public service model of Canadian broadcasting. The CCAU argues it is both the role and responsibility of the state to intervene where the market has failed, and uphold the objectives of the Broadcasting Act not in partnership with business, but often in spite of it. CCAU support for CRTC initiatives, even if only partial as with the case of the recently announced incentives package, provides the state support from organized labour, aiding in improved relations between the state and the workers who are the Canadians in Canadian content. For scholars who extrapolate the specific role of labour to a larger picture of civil society, the participation of labour in the policy network can also be seen to facilitate improved accountability and relations between the state and the publics it is mandated to represent. Labour's participation in the broadcasting policy network not only legitimates the state. The state's engagement with the unions, as evidenced in both formal and informal consultations, legitimizes and politicizes the voice and role of labour in the policy process, improving labour's power and profile both publicly and within the policy community.

The complexity of labour's relationship to the state is revealed in the conditions under which they provide support to the CRTC. The unions fundamentally challenge the policy paradigm that emphasizes a market approach to cultural undertakings. The CCAU's recommendations include measures to improve the democratic administration and accountability of the broadcasting system through enhanced transparency in reporting measures, challenging the tendency toward selfregulation. The CCAU's brings the issue of dramatic programming into broader public 
discourse, publicizing the policy issues as those that not only affect the constituent interest groups of the policy network, but as issues that affect all Canadian viewers as Canadian citizens. This further serves to challenge trends that position viewers as primarily economic, rather than political constituents of Canadian broadcasting. The unions' ability to fundamentally challenge both the policy rationale and power relations within the system holds promise for increased democratic administration of the system as a whole. 
CHAPTER FIVE - Labour and the Representation of Interests in Policy Advocacy

Before examining whether the unions operate primarily in the interests of their members, or reflect a genuine engagement with broader social objectives as policy network actors, it is first important to analyze each of the unions in terms of their profile as either members of the subgovernment or attentive public within the policy network. In closing, I make strategic recommendations as to how the unions can improve their power and position both as constituent interest groups and as civil society organizations.

\section{Attentive public / subgovernment}

The subgovernment is defined as those policy actors who wield significant influence in policy formation and decision making processes. The attentive public is defined as those members of the policy community who follow and attempt to influence policy, but do not directly participate in the decision making process (Atkinson and Skogstad 1996, Pross 1992).

IATSE has several characteristics that clearly identify it at best as a member of the attentive public. First and foremost, it cannot be said to hold regular, routine interaction with the state. While IATSE is beginning to foray into policy, as indicated by their submission to the Feature Film Advisory Committee, the Director of

Canadian Affairs stated no plans to engage specifically with Canadian broadcasting issues as a concern for the Canadian locals, nor has IATSE ever engaged with the CRTC. However, IATSE is a member of the relatively new Canadian Film and Television Industry Committee (CFTIC), a national pan-industry association formed to 
address issues facing the industry for both domestic and foreign service production. The focus for CFTIC at the moment is funding for the Canadian Television Fund, tax credit structures and administration, and long term, stable funding for the CBC. Furthermore, it should be noted that several IATSE locals have been independently involved in policy related initiatives on provincial and municipal levels. Mimi Wolch, IATSE Ninth International Vice President and Business Agent for Local 873 in Toronto, and Rick Perotto, Business Representative for Local 667 of Eastern Canada are on the Board of Directors for FilmOntario, a provincially based industry coalition that was central in successfully lobbying for an increase in Ontario's provincial film and television tax credits in 2004. Rank and file members from Locals 873, 667 and 411 were also involved in the grassroots Keep Ontario Cameras Rolling Coalition formed in 2004 to support the formal lobbying activities of FilmOntario around the provincial labour tax credits. Ms. Wolch is also the labour representative on the City of Toronto's Film, Television, and Commercial Production Industry Committee.

There are still some fundamental structural obstacles that must be addressed within IATSE before they can become as effective in policy as other national unions in the Canadian film and television industry. IATSE has no formal communication structure between the Canadian Office and the Locals either by means of regular publications dedicated to Canadian concerns, nor a formal reporting structure, or a formal apparatus by which the Locals communicate with each other in any other regard other than the yearly Canadian convention. On a national level, IATSE is poor in human resources and expertise specific to policy. The disaggregated and decentralized organization of IATSE on a national level, combined with its distant 
relationship with other unions in regard to policy approaches and general disinterest in issues specific to the domestic television production industry, operate as impediments to IATSE's ability to be considered active members of the attentive public, let alone subgovernment, in the Canadian broadcasting policy community.

The CEP recognizes that it is relatively new to the network as a strong representative of the English independent film and television production sector. The CEP makes sure to keep its position as a labour organization for broadcasters' employees in perspective through only providing expertise and time from the National Office, leaving all financial contributions up to locals specific to the sector. However, the CEP's size as the third largest private sector union in Canada lends it considerable strength, and its history with political activism and engagement with issues concerning the broader public interest in multiple sectors make it a powerful force in the policy environment. Perhaps in what could be considered a transitory stage in the broadcasting policy arena, the CEP is positioning itself, through the use of its considerable resources, expertise and recent affiliation with other members of the independent production sector, to be considered a committed and knowledgeable member of the policy community, involved in the network in such as way as to be rapidly moving from attentive public to subgovernment.

ACTRA, the DGC and the WGC, each with much longer histories specific to policy interventions in the broadcasting sphere, are significantly closer than the other two unions in being considered members of the subgovernment. As individual organizations, by 1998 all had reached a certain degree of recognition within the policy community and were consulted by the government on policy related concerns. 
Their national organization and policy-dedicated resources facilitated their ability to monitor the policy environment and make regular policy inputs. They also shared a basic level of cooperation and communication as labour representatives of the English independent production sector, although their policy positions remained diverse.

It is the conclusion of my analysis that the formation and actions of the CCAU has cemented labour's presence, or that of ACTRA, DGC, WGC and CEP to be more specific, as members of the subgovernment in the policy sphere. Through their advocacy coalition framework, they are able to pool expertise and resources that allows them to constantly monitor the policy environment as well as swiftly and knowledgably respond both to requests from the government for advice with regard to policy as well as policy developments after implementation. The formation of the CCAU, with the support and encouragement of Heritage Minister Sheila Copps, indicated to the broadcasting policy network that labour was serious about their commitment and role in the policy sphere, and could set aside differences of opinion and approaches in coming together to broaden their base of support and reflect the needs of the Canadian independent production sector with one cohesive voice. As Pross (1992) notes, admission to the circle of the subgovernment is recognition of the group's policy capacity, and members of the subgovernment share a power relationship with a government agency. Although Pross' model does not effectively account for coalition frameworks, it is clear that the CCAU's thorough research and detailed proposals have indicated to the state that labour has developed the policy 
capacity required to be admitted to the inner workings of the broadcast policy sphere.

\section{Unions and the public interest}

Returning to questions of terminology in the literature regarding group behaviour in policy communities and policy networks, I argue that the problem lies not with the various terms themselves, but in how they are taken up in the literature, used to render certain groups static within a given category when in fact their activities and behaviours may require a much more fluid understanding of their status. In reviewing its activity in the policy arena, IATSE cannot be considered a constituent interest group as defined in chapter one, as it cannot reasonably be argued that its behaves in a political fashion with respect to Canadian broadcasting policy. The CEP, ACTRA, DGC and WGC can reasonably be argued to be constituent interest groups, since their policy advocacy clearly works to the benefit of their membership. As the CCAU, the unions could be argued to be an advocacy group (as defined by Everitt and Young 2004), whose policy activities reflect not only a commitment to their members interests but also to a broader public interest.

The remaining question is whether their arguments, anchored in social and cultural objectives, would continue to be pursued if such ideals did not dovetail with their members' interests. Such arguments are clearly convenient when the industrial circumstances of Canadian dramatic programming render economic arguments impotent. This is by no means to contend that the arguments made for the value of Canadian dramatic programming by the unions are insincere, where the unions 
simply exploit the notion of the public interest to their own ends. What I am arguing is that the unions have not provided enough evidence to date that their engagement with broader social and cultural issues is not predicated on such issues coinciding primarily in the best interests of their members. For example, while the CEP explicitly stated their devotion to working in the public interest in their policy advocacy, they make financing for research and campaigns on the issue of dramatic programming the responsibility of the much smaller and less wealthy locals. This calls into question their allegiance to dramatic programming as a central cultural component of the broadcasting system's ability to operate in the public interest. Although many CEP members work for broadcasters, a commitment to dramatic programming, as an essential tool of social cohesion and national identity, theoretically should not interfere with the interests of members who are employed by the broadcasters, for those members, as citizens, would benefit equally from an increase in Canadian dramatic programming.

In practical terms, it is not in the interests of the unions to advocate for policies (regarding dramatic programming or otherwise) that pose a conflict of interests for the members they represent. However, should the unions wish to expand their policy platform and deepen their level of engagement as civil society organizations, there are several strategic steps that can be taken to reinforce their commitment to working in the public interest and improve their position and influence in the Canadian broadcasting policy network. 


\section{Strategic recommendations}

Key to successful policy activity, or the general success of any union, is engagement of the rank and file (Schenk 2003). There are structural challenges to engagement of the rank and file within the Canadian independent production community. Work places are not static - workers are independent freelancers whose job status and location changes from one day to the next, even within a single production. Some workers are core crew members, others are daily or weekly labour calls. Writers are possibly the most isolated, and they often do not interact with other writers or the rest of the production crew at all. Actors' jobs are highly volatile, with engagements often lasting only a day or so. Series productions, particularly those that go for multiple seasons, offer the greatest job stability, but as evidenced, those jobs are increasingly scarce in the domestic industry. Contract and transitional working environments are characteristic in a globalized employment landscape, but this does not easily facilitate union engagement and commitment between members, particularly when your co-workers are changing on a regular, if not almost daily, basis. Nevertheless, engagement of the rank and file in political activity is not an impossible task.

ACTRA considers itself an activist union and their public activities indicate a fairly engaged membership. As one example, ACTRA encouraged their members to pressure politicians on cultural issues during the federal 2004 election campaign, with ACTRA members making appearances at town hall meetings, radio call-in shows and sending letters to editors of local papers (Thompson 2004). Grassroots engagement is starting to be evidenced in the other unions, particularly at the local 
or regional levels. In a recent example of grassroots activism in Ontario, members of IATSE Locals 873, 667 and 411, the DGC Ontario District Council, NABET Local 700 and ACTRA Toronto formed the issue based, ad-hoc Keep Ontario Cameras Rolling Coalition and, in support of more formal lobbying efforts by the provincial industry advocacy coalition FilmOntario, staged a rally in November of 2004 at the provincial legislature in pressuring the Ontario Liberal government to increase the level of provincial labour tax credits and bring them in line with other production regions across Canada. Rank-and-file members operated in concert with each other (in fact, in a similar fashion to the way these members work together every day on a film or television set), drawing upon their own expertise and connections through their trade in the industry to pull together a remarkably quick mobilization of the industry at large. Good turnout at the rally from members of all unions indicates a political willingness at the grassroots level that can be further exploited for political and organizational benefits. A motivated and mobilized membership is generally understood to be good for the internal health of a trade union, and grassroots support for political issues lends credence to more formal lobbying activities. The ability of union representatives to take lobbying efforts from the formal (as in FilmOntario) to grassroots (as in KOCR) while maintaining a consistent message evidences adaptability, flexibility and a good relationship with their membership that will serve both the organizations and their political goals well.

Schenk (2003) argues one of the means by which a union's membership can be engaged and empowered is through building alliances and coalitions with key community or sector resources in developing an understanding of both labour 
specific and broader social issues. An educated, empowered membership will foster a stronger union through increased participation and commitment to democratic ideals required to challenge prevailing political and economic paradigms. Further to a cross-sector engagement of unions in a coalitioned or allied fashion, Johnston (2004) outlines how unions have turned to engaging other groups and the public at large in seeking broader social change in a marked increase in political activity that leaves unionism ready at any moment to succeed as a larger social movement. Murray notes that in order for a policy issue to be considered a broader social movement, the concerns for and level of engagement with the issues at stake must extend beyond the limits of the policy community to a larger social audience, further noting this has not yet come to pass with cultural policy issues in Canada (2002). Policy community members must expand their coalition network, develop linkages and deepen understandings with other sectors in forming a rights-based, social justice platform for public engagement and participation (Fox 2001, Murray 2002).

Drawing heavily on concepts of rights and citizenship in a democratic political system, social movement unionism is networked with other social justice based advocacy groups. By positing the labour movement as a citizenship movement, a rights based discourse enters the framework, allowing for alignment and direct engagement with other democratic social movements. The basis for framing claims under the citizenship model for the labour movement is to move away from threats to the specific workforce or sector, and re-frame them as threats to the social, cultural and economic future of the community. Johnston (2004) uses the concept of 
citizenship beyond formal political participation to the relationship of an individual to their public institutions. Rights extend beyond those enshrined legally to include those that are claimed and/or have been denied and drive social movements.

Citizenship is historically deconstructed as a set of power relations, as "the power to define and implement the 'public interest,' a power that typically, behind the veil of [the] public interest, always favours one private interest or another" (ibid: 242). Citizenship movement unionism does not privilege labour itself, but rather operates on the notion that the labour movement will be fully actualized when it has successfully aligned and merged with other social movements, allowing its members to represent themselves as workers but also and equally as citizens with other, multiple interests and identifications.

The unions studied here have an excellent opportunity to fundamentally complicate the 'viewer as consumer' perspective that appears to be dominating the broadcasting policy environment (evident in the economic models, rhetoric of 'choice' and focus on audience numbers) through the engagement of other interest groups that share concerns from a cultural standpoint about the importance of diversity, representation, identity and cultural expression. Interest groups involved in advocacy work on issues of concern to women, gay and lesbian, aboriginal, disabled, racialized, ethnicized and educational communities (to name but a few who have a stake in such issues) should be approached in the interests of expanding the issue to additional publics and framing the issues in concepts of citizenship that challenge traditional notions of national identity and the ability of the Broadcasting Act to, "reflect the circumstances and aspirations, of Canadian men, women and 
children, including equal rights, the linguistic duality and multicultural and multiracial nature of Canadian society and the special place of aboriginal peoples within that society (Canada, 1991)".22

Fox argues that one of the central tools for effective policy advocacy is vertical policy monitoring. In order for civil society organizations to remain informed and adaptable to the rapidly changing and unstable policy environment, they must not focus too narrowly on the activities of one level of government. Too narrow a scope risks what Fox terms a problem of "squeezing the balloon," wherein directing attention, or "squeezing" one level of government causes the ball to be passed to another, resulting in the problem "popping out" elsewhere (2001: 618). Those national film and television unions active in policy evidence some degree of integrated policy monitoring, recognizing that federal departments or agencies directly responsible for culture are by no means the only state actors in the policy process, interacting with departments such as Finance, DFAIT and Industry as part of their regular strategies. While broadcasting policy is formulated and implemented on a national level, related industrial and cultural concerns are debated and articulated at all state levels, from issues of urban and rural representation to the viability of domestic content regulations within the context of multilateral trade agreements.

The DGC, with its involvement at regional, federal and international levels, evidences the most integrated approach to policy monitoring and intervention. ACTRA is active on regional and federal levels, but would be well served by a greater engagement in the international arena. While the Writer's Guild is active federally and internationally, they are notably absent in regional activities. As the national 
parent union, CEP is only active on federal and international levels, and the independent production sector affiliate locals are totally inexperienced in the policy arena at any level, drawing heavily from the skills and expertise of the CEP and other labour groups in any local or regional coalitions they join. While independent IATSE locals appear to be engaging in their jurisdictional policy arenas, they must establish a mechanism for policy monitoring at federal and international levels. Finally, the new emerging role of cities as political subjects for federal concern would also indicate a potentially important location for policy monitoring, consulting and advocacy for the film and television community. The value of a coalition based strategy becomes heir apparent in this case. With all the member unions involved in various and different levels of policy monitoring and membership engagement, a coalition strategy enables organizations to draw on the knowledge and experience of their fellow members in developing organizational and political strategies in their own right.

It is evident that the unions do not operate as a homogeneous group within the Canadian broadcasting policy network, even as members of the CCAU. From IATSE's relative isolation from the policy community to ACTRA's engagement of their celebrity members in the public sphere to the DGC's international activities, it is clear that the discussion of these unions under the typology of 'organized labour' is no more useful in accurately describing their actions as policy actors than is the umbrella term, 'civil society organization'. Only when the unions themselves choose to operate in a cohesive fashion, such as in the case of the CCAU, can they be 
discussed as a group, and even then there are clearly specific contributions or skills that each individual member group brings to the table. Pross' model is most useful in this case not to highlight a group typology, but rather to reveal the heterogeneity of constituent interest groups within the broadcasting policy network, even those whose general structure (as a labour unions) would lead imprecise discursive practitioners to speak of as a whole.

My analysis evidences that the four of the five national film and television unions are active members of the Canadian broadcasting policy network and contribute to the network's capacity to formulate, implement and evaluate the effectiveness of policy. The adoption of a coalition based strategy has positively impacted the unions' positions within the broadcasting policy network. The unions draw on their respective strengths in contributing to the coalition framework, while gaining valuable support and legitimacy from the collective actions of their labour colleagues. This pooling of resources has positioned them as credible, informed and proactive players on the broadcasting policy landscape. The unions clearly enter the policy network as representatives of their members' interests. As the definition of the public interest in Canadian broadcasting neatly coincides with the unions' members' interests, the unions also operate to challenge the prevailing policy paradigm that privileges corporate interests through invoking arguments based on social and cultural objectives of the public service broadcasting model.

There is a great deal of research to be yet to be undertaken in this field. In developing a body of work specific to Canada, future research could include analyses of the relationship of the French-language film and television labour organizations to 
their specific markets and policy networks, as well as the role of labour in the development, implementation and evaluation of policy regarding other cultural industries and arts sectors. Analyses specific to the other layers of the state (municipal, provincial, continental and international) is necessary to gain an accurate perspective of labour's relationship to cultural policy in all its interconnected jurisdictions. Comparative analyses with arts and cultural industries and labour organizations in other countries that share similar regulatory frameworks or approaches to cultural policy would also be of value in mapping the role of labour in cultural policy networks. The research will only become more relevant as policy jurisdictions become increasingly intertwined, the value of arts and culture in social and industrial terms evolves, and as civil society organizations develop more sophisticated linkages in policy processes. Understanding where labour is situated in this landscape is key, as labour brings the voices of the artists and other creative workers to the policy table, voices that are seen as increasingly important from social, cultural and economic perspectives.

\footnotetext{
${ }^{1}$ Some of the labour organizations in this study are technically classified as guilds rather than unions. In keeping with both industry and broadcasting policy vernacular, the groups within this study will be collectively referred to as unions or organized labour.

2 Interviews, were conducted with Peter Murdoch, VP-Media for the Communication, Energy and Paperworkers Union (CEP); Pamela Brand, National Executive Director and CEO of the Director's Guild of Canada (DGC); Gail Martiri, Director of Policy for the Writers Guild of Canada (WGC); Ken Thompson, Director of Public Policy and Communications for the national office of the Alliance of Canadian Cinema Television and Radio Artists (ACTRA); and John Lewis, Director of Canadian Affairs for the International Alliance of Theatrical and Stage Employees, Moving Picture Technicians, Artists and Allied Crafts of the United States, Its Territories and Canada (IATSE). In viewing the other side of the policy table, I also interviewed Charles Dalfen, Chair of the Canadian Radio-television and Telecommunications Commission (CRTC).

${ }^{3}$ Such language is easily located in the 1999 Television Policy, and reflects the impact of this approach to the provision of public services within the Canadian broadcasting system. This will be examined in greater detail in Chapter two.

${ }^{4}$ See Chapter two for excerpts from the 1991 Broadcasting Act concerning its public interest objectives.
} 
5 It should be noted that many other government departments and agencies are involved either directly or peripherally with the development of Canadian broadcasting policy within the policy network, although a few are of more importance than others. Those involved less directly in the core of broadcasting policy and regulation include Human Resources and Skills Development Canada who set and administer guidelines for the issuance of foreign worker permits for the foreign service sector; the Department of Foreign Affairs and International Trade, who promote Canadian cultural expression and products internationally and act as advisors on issues concerning international trade through the Cultural Industries Sectoral Advisory Group on International Trade (SAGIT); the Canada Revenue Agency who administers the various federal tax incentive programs offered to both domestic and foreign productions; and the Department of Industry who has control over foreign ownership regulations for broadcasters, for example.

The House of Commons operates the Standing Committee on Canadian Heritage that reports regularly to Parliament on various issues that fall under their jurisdiction. Most recent and politically charged is the their report, Our Cultural Sovereignty: The Second Century of Canadian Broadcasting chaired by Clifford Lincoln (Standing Committee 2003). Making over ninety recommendations on the policy direction and administration of the Canadian broadcasting industry, the much anticipated report generated significant industry buzz when it was released in 2003.

More central to the policy network and the attention of constituent interest groups are the Department of Finance which, in its budget setting capacity, determines the amount and duration of funding available through various programs and initiatives, and the Department of Canadian Heritage. The Department of Canadian Heritage oversees all of Canada's cultural policies and industries. Governed by the Canadian Heritage Act, the department is responsible for policies and programs related to broadcasting, publishing, sound recording, film and video production, arts, heritage, official languages, Aboriginal cultures and languages, Canadian identity, citizens' participation, youth, multiculturalism and sport (Canadian Heritage 2005). The Canadian Heritage portfolio includes the department and nineteen other organizations and crown corporations related to the support and promotion of Canadian artistic and cultural expression. Specific to broadcasting, the portfolio includes the CBC, Telefilm, the CRTC and the National Film Board. While all the broadcasting agencies and crown corporations enjoy varying degrees of arms-length status, the Minister of Canadian Heritage is, "responsible for ensuring that the major orientations of the agency and Crown Corporations within the portfolio support the Government's goals and priorities. The Minister is also responsible to Parliament for the resources allocated to all organizations in the portfolio" (ibid). ${ }^{6}$ For a thorough description of the limitations of the Canadian domestic television market, see Jeffrey, Liss. (1996) "Private Television and Cable" The Cultural Industries in Canada: Problems, Policies and Prospects. Ed. Michael Dorland. Toronto: James Lorimer \& Company

${ }^{7}$ The most recent CRTC definition of dramatic programming includes the following:

On-going dramatic series; On-going comedy series (sitcoms); Specials, mini-series, and madefor-TV feature films; Theatrical feature films aired on television; Animated television

programs and films (excludes computer graphic productions without story lines); Programs of comedy sketches, improvisations, unscripted works, stand-up comedy; Other drama,

including, but not limited to, readings, narratives, improvisations, tapes/films of live theatre not developed specifically for television, experimental shorts, video clips, continuous action animation (e.g. puppet shows). (CRTC 1999a)

${ }^{8}$ See Florida, Richard L. (2002) The Rise of the Creative Class: and how it's transforming work, leisure, community and everyday life. New York: Basic Books

${ }^{9}$ Film and television production activity generated 134,700 direct and indirect full time equivalent jobs for 2003/2004 (CFTPA 2005).

${ }_{10}$ For example, Degrassi: The Next Generation signed collective agreements with ACTRA for cast, DGC for key creative $\mathbb{E}$ logistical personnel as per their jurisdiction, NABET 700-CEP for technicians, the WGC for writers and IATSE 667 \& 411 for camerapersons and production coordinators, honeywagon drivers and craft service providers respectively. 
11 Independent production refers to those productions not undertaken in-house by private broadcasters or those done at the CBC.

${ }^{12}$ As certified through either the CRTC and/or CAVCO processes.

${ }^{13}$ In house broadcaster production accounts for the remaining $21 \%$ of production volume for that year.

${ }^{14}$ Technician categories include grips, electrics, sound, hair, makeup, wardrobe, transport, props, set decoration, carpenters, painters, special effects and script supervisors.

${ }^{15}$ For example, the DGC represents Production Coordinators in Alberta, but IATSE represents them in Toronto.

${ }^{16}$ The WGC is the only union in this study that does not allow non-members access to their constitution. Historical and organizational information is taken from staff consultations and what is available on the website. No formal history of the Writers Guild of Canada is available in print to date.

${ }^{17}$ The ACFC Local 2020 in Vancouver has not to date joined the Coalition of Canadian Audio-visual unions, nor appears to be involved in federal policy issues as a local of the CEP. NABET Local 700 in Toronto made all financial contributions to the CCAU work as the CEP local from the Canadian independent broadcasting sector.

${ }^{18}$ Both the Executive Director of the WGC and Executive Director/CEO of the DGC are Vice Presidents of the Coalition for Cultural Diversity.

${ }^{19}$ The points system is employed in two different areas of broadcasting. The Canadian Audio-Visual Certification Office uses the point system to determine the amount of tax credit allowed and provisional CAVCO certification is required for funding from the Canadian Television Fund. The CRTC uses a similar point system for determining Canadian content that qualifies toward priority programming requirements set out by CRTC regulations. Under both systems, points are determined through the following number of positions that are filled by Canadians: Director (2 points), Screenwriter (2), Lead Performer (1) $2^{\text {nd }}$ Lead (1), Director of Photography (1), Art Director (1) Music Composer (1), Picture Editor (1).

${ }^{20}$ In dealing with the implications of the 1999 Television Policy, the Coalition is specifically addressing the English market, and while the French members support the positions of the English organizations, only those organizations directly involved with English dramatic production contribute expertise and resources for the Coalition's activities in that regard. When the Coalition engages with issues concerning the French-Canadian market, a reciprocal framework applies.

${ }^{21}$ Related issues include parliamentary allocations for the Canadian Television Fund, the primary source of government funding required to put most domestic dramatic series into production. 22 The 2004 Report of the Task Force for Cultural Diversity is another example of how the Canadian broadcasting system is failing in this regard. See "Reflecting Canadian: Best Practices for Cultural Diversity in Private Television". http://www.cab-

acr.ca/english/social/diversity/taskforce/report/cdtf_report_jul04.pdf 
Alliance of Canadian Cinema Television and Radio Artists (2002). Independent Production Agreement between the Alliance of Canadian Cinema, Television and Radio Artists and the Canadian Film and Television Production Association and L'Association Des Producteurs De Films Et De Television Du Quebec covering Peformers in Independent Production, January 1, 2002 to December 31, 2003.

-... (2003). ACTRA Constitution. January 3.

…. (2004). www.actra.ca

.... (2005). Press release: Steelworkers, ACTRA Join Forces in Strategic Alliance, Service Agreement. April 13. http: / / www.actra.ca/actra/control/press news1?id=10367. Site accessed May 25,2005

Association of Theatrical Press Agents and Managers. (2005) Introduction to the I.A.T.S.E. www. atpam.com/lATSE/itaseintro.htm. Site accessed February 2.

Atkinson, Michael M. and Coleman, William D. (1996). "Policy Networks, Policy Communities, and the Problems of Governance" in Policy Studies in Canada: The State of the Art. Ed. L. Dobuzinskis, M. Howlett, D. Laycock. Toronto: University of Toronto Press

Azzi, Stephen and Feick, Tamara. (2003) "Coping with the Cultural Colossus: Canada and the International Instrument on Cultural Diversity." Coping with the American Colossus. Ed. David Carmend, Fen Osler Hampson and Norman Hillmer. Don Mills: Oxford University Press

Bakan, Joel (2000). "The Significance of the APEC Affair" Pepper in Our Eyes: the $A P E C$ Affair. Ed. W. Wesley Pue. Vancouver: UBC Press

Bracken, Laura (2004). "ACTRA grows into lobbying force" Playback February 16, p. 17.

Brand, Pamela (2005). Interview with the author. March 10, Toronto.

Bertrand, Francoise. (1999). The New CRTC Policy on Canadian Television: More Flexibility, Diversity and Programming Choice. Notes for an address to a news conference announcing the new CRTC policy on Canadian television. Hull: 11 June

Canada. Broadcasting Act (1991, c.11 as amended). http://laws.justice.gc.ca/en/B9.01/text.html. Site accessed 15 September 2003 
Canadian Audio-Visual Certification Office. (2005). http://www.pch.gc.ca/progs/acca/progs/bcpac-cavco/index_e.cfm. Site accessed 8 August 2005.

Canadian Coalition of Audio-visual Unions. (2002) Rejuvenating Canadian Series Drama Production: A Position Paper Prepared by The Coalition of Canadian Audio-visual Unions. http://www.actra.ca/actra/images/02sept/.pdf Site accessed $15 \cdot$ January 2004.

-..- (2003) The Crisis in Canadian English-Language Drama. http://www.actra.ca/actra/images/03march/CCAUCrisis.pdf Site accessed 10 November 2003.

.... (2003a) Addressing The Crisis in Canadian English-Language Drama. Submission of the Coalition of Canadian Audio-visual Unions to the CRTC re: Public Notice CRTC 2003-54: Support for Canadian Television Drama. November 28, 2003. http://www.actra.ca/actra/images/03dec/CCAU-DRAMA\%20BRIEF.pdf Site accessed 19 January 2004

-.-. (2004) Re: Public Notice CRTC 2004-32 - Call for comments on proposed Incentives for English-language Canadian television drama - Submission of the Coalition of Canadian Audio-Visual Unions. www.crtc.gc.ca Site accessed 3 February 2005

-.-. (2004a) Re: CTF Governance Proposals. Letter to Susan Peterson, Associate Deputy Minister, Department of Canadian Heritage. September 21.

-.-. (2005) The Need For A Regulatory Safety Net: Broadcasting Policy and Canadian Television Drama in English Canada in the Next Five Years. http://www. friends.ca/files/PDF/CCAUSafetyNetreportJune13-2005.pdf. Site accessed 20 July 2005

Canadian Film and Television Production Association (CFTPA) (2005). Reversal of Fortune: the Need to Forge a New Strategy for Canadian Production.. Profile 2005 - An Economic Report on the Canadian Film and Television Production Industry. February.

Canadian Press (2004). "Actors to ask Ottawa for more TV-drama funding" The Globe and Mail, Saturday October 4, p.R6.

Canadian Radio-television and Telecommunications Commission. (1983) Public Notice 1983-18 Policy Statement on Canadian Content in Television. Ottawa: 31 January 
-... (1998). Subject: Canadian Television Policy Review. Transcript of Proceedings for the Canadian Radio-Television and Telecommunications Commission. Hull, Quebec: October 1.

-..-. (1998a). Subject: Canadian Television Policy Review. Transcript of Proceedings for the Canadian Radio-Television and Telecommunications Commission. Hull, Quebec: October 2

-.-. (1998b). Subject: Canadian Television Policy Review. Transcript of Proceedings for the Canadian Radio-Television and Telecommunications Commission. Hull, Quebec: October 5

-... (1998c). Subject: Canadian Television Policy Review. Transcript of Proceedings for the Canadian Radio-Television and Telecommunications Commission. Hull, Quebec: October 7

-... (1999) Public Notice CRTC 1999-97 Building On Success - A Policy Framework for Canadian Television. Ottawa: 11 June

-.-. (1999a) Public Notice CRTC 1999-205 Definitions for new types of priority programs; revisions to the definitions of television content categories; definitions of Canadian dramatic programs that will qualify for time credits towards priority programming requirements. Ottawa: 23 December

-..-. (2000) Public Notice CRTC 2000-42: Certification for Canadian Programs - $a$ revised approach. 17 March

-..-. (2001a). Decision 2001-458. Licence renewals for the television stations controlled by Global. Ottawa: 2 August

-..-. (2001b). Decision 2001-457. Licence renewals for the television stations controlled by CTV. Ottawa: 2 August

-.-. (2003) Broadcasting Public Notice 2003-54: Support for Canadian television drama - Call for comments. Ottawa: 26 September

-..-. (2004) Broadcasting Public Notice 2004-32. Proposed incentives for Englishlanguage Canadian television drama - Call for comments. Ottawa: 6 May

.... (2004a). Broadcasting Public Notice 2004-93: Incentives for English-language Canadian television drama. Ottawa: 29 November

-... (2005) About the CRTC. http:// http://www.crtc.gc.ca/eng/about.htm Modified 2005-04-28.

Canadian Television Fund (2005) www.canadiantelevisionfund.ca 
Clarkson, Stephen. (2001) "The multi-level state: Canada in the semiperiphery of both continentalism and globalization" Review of International Political Economy. Vol. 8 No. 3: 501-527

Communication, Energy and Paperworkers Union of Canada (CEP) (2002). Constitution of the Communications, Energy and Paperworkers Union of Canada.

..... (2004) For Democratic Canadian Media. Proposed Media Policy by the CEP Executive Board June 2004 for the October National Convention, Quebec City.

Communication, Energy and Paperworkers Union of Canada (CEP) (2005). www.cep.ca

Crelinsten, Ronald D. (2001) "Policy Making in a Multicentric World: The Impact of Globalization, Privatization, and Decentralization on Democratic Governance" Who is Afraid of the State? Canada in A World of Multiple Centres of Power. Ed. Gordon Smith and Daniel Wolfish. Toronto: University of Toronto Press

Dalfen, Charles. (2002). Is Canadian TV Drama Possible? Notes for an address to the ACTRA Toronto Performers Plenary. November 6. Www.crtc.gC.ca/ENG/NEWS/SPEECHES/2002/s021106.htm. Site accessed October 14, 2003.

..-. (2003). A balancing act: Local and national broadcasting. Notes for an address to the Communication, Energy and Paperworkers Union of Canada (CEP) Media Council Conference. April 23. wWw.crtc.gC.ca/eng/NEWS/SPEECHES/2003/s030426.htm. Site accessed October 20,2003

-..-. (2005). Interview with author. 3 February, Ottawa.

Department of Canadian Heritage (2005). www.pch.gc.ca

Director's Guild of Canada (DGC) (2000) Vision Statement - Membership Application. http://www.dgc.ca/PHPUploads/Membership\%20Application_2005.pdf. Site accessed 10 October 2004

-..- (2003). DGC National Constitution. http://www.dgc.ca/PHPUploads/Constitution_October_2003.pdf. Site accessed 4 October 2004

-..- (2004). www.dgc.ca.

-... (2004a) DGC in the Policy Arena. Newsletter \# 18, Fall. 
Dorland, Michael (1996). "Cultural Industries and the Canadian Experience" The Cultural Industries in Canada. Ed. Michael Dorland. Toronto: James Lorimer and Company

-..- (1998). So Close to the State/s: The Emergence of Canadian Feature Film Policy. Toronto: University of Toronto Press.

Dwivedi, O.P. and and Gow, James lain. (1999). From Bureaucracy to Public Management: The Administrative Culture of the Government of Canada. Peterborough: Broadview Press.

Ernst \& Young (2004). Econometric Study of Ontario Film and Television Tax Credits. Jointly commissioned with FilmOntario, the Ontario Media Development Corporation and the Canadian Film and Television Production Association. http://www.filmontario.ca/documents/EandYEconometricStudy2004.pdf Site accessed 04/01/05.

Fraser, Nancy (1993) "Rethinking the Public Sphere: A Contribution to the Critique of Actually Existing Democracy" in The Phantom Public Sphere. Bruce Robbins, ed. Minneapolis: University of Minnesota Press. Pp. 1-32

Fox, Jonathan. (2001) "Vertically Integrated Policy Monitoring: A Tool for Civil Society Policy Advocacy" Non Profit and Voluntary Sector Quarterly Vol. 30, No. 3: 616-627

Gattinger, Monica. (2003) "Creative Pique: On Governance and Engagement in the Cultural Sector" Accounting for Culture Colloquium. Gatineau: Strategic Research and Analysis (SRA), Department of Canadian Heritage

Harvey, Sylvia. (2004) "Living With Monsters: Can Broadcasting Regulation Make a Difference?" Toward a Political Economy of Culture: Capitalism and Communication in the Twenty-First Century. Ed. Andrew Calabrese and Colin Sparks. Lanham: Rowman \& Littlefield Publishers Inc.

International Alliance of of Theatrical and Stage Employees, Moving Picture Technicians, Artists and Allied Crafts of the United States, Its Territories and Canada (IATSE). (2001). Constitution and Bylaws, 64 $4^{\text {th }}$ Editiion. Adopted July 20.

-.... (2004). www.iatse-intl.org

Jacobs, Ronald N. (2000) Race, Media and the Crisis of Civil Society: From Watts to Rodney King. Cambridge: Cambridge University Press.

Johnston, Paul (2002) "Citizenship Movement Unionism: For the Defense of Local Communities in the Global Age" Unions in A Globalized Environment: Changing 
Borders, Organizational Boundaries and Social Roles Ed. Bruce Nissen. New York: M.E. Sharpe

Karim, Karim H. (1998). From Ethnic Media to Global Media: Transnational Communication Networks Among Diasporic Communities. Gatineau: Strategic Research and Analysis (SRA), Department of Canadian Heritage

Lewis, John (2005). Interview with author. February 15, Toronto.

...- (2005a) "Re: Standing Committee on Canadian Heritage Review of the Canadian Feature Film Industry" Letter to the House of Commons Standing Committee on Canadian Heritage. March 11.

Macdonald, Laura C. (2002) "Governance and State-Society Relations: The Challenges" in Capacity for Choice: Canada in a New North America. Ed. George Hoberg. Toronto: University of Toronto Press

Martiri, Gail. (2005). Interview with the author. 23 March, Toronto.

MCDowell, Stephen. (2001) “The Unsovereign Century: Canada's Media Industries and Cultural Policies" in Media and Globalization: Why the State Matters. Ed. Nancy Morris and Silvio Waisbord. Maryland: Rowman \& Littlefield Publishers Inc.

McQueen, Trina. (2003). Dramatic Choices: A report on Canadian English-language drama. Jointly commissioned by the CRTC and Telefilm Canada. www.crtc.gc.ca/eng/publications/reports/drama/drama2.htm. Site accessed March 1, 2004.

Murdoch, Peter (2005). Interview with the author. 4 February, Ottawa.

Murray, Catherine A. (2002) "The Third Sector: Cultural Diversity and Civil Society" Canadian Journal of Communication Vol. 27: 331-350

Newman, Jacquetta and Tanguay, A. Brian (2002). "Crashing the Party: The Politics of Interest Groups and Social Movements" in Citizens Politics: Research and Theory in Canadian Political Behaviour. Toronto: Oxford University Press

Ontario PC Party (2004). “Press Release: Action! Ontario's Film Industry needs Tax Credits - Now."November 29. http://www.ontariopc.com/main_fr.asp?.htm. Site accessed 29/11/04.

Pal, Leslie A. (2001). Beyond Policy Analysis: Public Issue Management in Turbulent Times. Toronto: Nelson Thompson Learning 
Peters, B. Guy and Pierre, John. (1998). "Governance Without Government? Rethinking Public Administration" Journal of Public Administration Research and Theory. Vol 8, No. 2: 223-243

Pross, Paul (1992) Group Politics and Public Policy. Toronto: Oxford University Press

Raboy, Marc and Taras, David (2004). "Transparency and Accountability in Canadian Media Policy" Communications Vol. 29: 59-76

Richardson, Jeremy (2000) "Government, Interest Groups and Policy Change" Political Studies Vol. 48: 1006-1025

Royal Commission on National Development in the Arts, Letters and Sciences. (1951). Report of the Royal Commission on National Development in the Arts, Letters and Sciences. Vincent Massey, Chair. Ottawa: Edmond Cloutier.

Sabatier, Paul A. (1991) "Toward Better Theories of the Policy Process" PS: Political Science and Politics Vol. 42, No. 2: 147-156

Salter, Liora (2004) "Publicly Speaking: Some thoughts on readings about the public, the public sphere and the public interest" unpublished chapter from forthcoming book, Playing Politics with Information: the Plainspeak Diaries.

Schenk, Christopher (2003) "Social movement unionism: beyond the organizing model" Trade Unions in Renewal: A Comparative Study Ed. Peter Fairbrother and Charlotte A. B. Yates. New York: Continuum

Standing Committee on Canadian Heritage. (2003) Our Cultural Sovereignty: The Second Century of Canadian Broadcasting. Canada: House of Commons.

Thompson, Ken (2004). "Election 2004: ACTRA speaks out for culture" Interactra. Fall

-... (2005) Interview with the author. 8 February, Toronto.

Uphoff, Norman and Krishna, Anirudh (2004). "Civil Society and Public Sector Institutions: More Than a Zero-Sum Relationship" Public Administration and Development Vol. 24: 357-372

Vamos, Peter (2003). "Acting in the name of culture” Playback July 21 p.11. Vamos, Peter. (2005) "Feds streamline TV funding" Playback June 20., p. 1. White, Pete. (2002) "The Beats: CRTC: The Time to Deal with Drama is Now" Canadian Screenwriter, Summer 
Writer's Guild of Canada (WGC) (2005). www.wgc.ca

Young, Lisa and Everitt, Joanna. (2004). Advocacy Groups. Vancouver: UBC Press.

(2) BC.74. 57 
